\title{
Association Between Polymorphisms in Cytokine Gene and Viral Infections in Renal and Liver Transplant Recipients: A Systematic Review
}

\author{
Prashant Sakharkar ${ }^{1}$, Subrata Deb ${ }^{2}$ and Nina Mashayekhi ${ }^{1}$ \\ 1. Roosevelt University College of Pharmacy, Schaumburg, IL, USA. ${ }^{2}$ Larkin University College of Pharmacy, Miami, FL, \\ USA.
}

Received, February 25, 2020; Revised, March 5, 2020; Accepted, April 22, 2020; Published, April 30, 2020.

\begin{abstract}
Purpose: Although transplantations are associated with an increased risk of post-transplantation infections, they greatly improve life expectancy and patients' quality of life. Cytokine genes play an important role in the success of transplants due to their immunological functions. A systematic review was conducted to evaluate cytokine gene polymorphisms and risk of cytomegalovirus (CMV), hepatitis B virus (HBV) and hepatitis $\mathrm{C}$ virus (HCV) infections in kidney and liver transplant recipients. Methods: A systematic search was conducted using PubMed, EMBASE, Medline and Google Scholar from their inception until January 28, 2019 using appropriate key words. Review articles, case reports or series, studies conducted on non-human subjects and published in languages other than English were excluded. Data were abstracted using a standardized form. The quality of the studies included was assessed using "Risk of Bias Assessment tool for Non-randomized Studies (RoBANS)". Results: Thirty-one studies met our inclusion criteria; populations studied were diverse with a sample ranging from 20 to 1,671. Nineteen studies evaluated Interleukin (IL)-28B polymorphism, while six studies evaluated interferon lambda (IFN- $\lambda$ ) gene polymorphisms and their impact on CMV, HCV, and HBV progression. Polymorphisms in IL-10 gene were investigated in six studies. Polymorphisms in IL-12B and IL-1B gene were associated with a higher risk of developing CMV infections while polymorphisms in IL-28B were associated with a lower incidence of CMV infection in renal transplant recipients. Similarly, polymorphisms in IL-28B were associated with higher liver dysfunction from HBV infection in liver transplant recipients. Studies included had low risk of bias. Conclusions: Cytokine gene polymorphisms IL-12B and IL-1B were found to be associated with an increased risk of infection in kidney transplants and IL-28B in liver transplant recipients. However, the small number and heterogeneity of studies limits the generalization of our results. Further research may lead to finding these associations in larger studies which perhaps improve the use of genetic testing and targeted antiviral therapy. This will further reduce the risk of viral infections associated with cytokine gene polymorphisms in post renal and liver transplant recipients.
\end{abstract}

Keywords: Cytokines; gene polymorphism; cytomegalovirus; hepatitis C; hepatitis B; CMV infection; renal transplant; liver transplant; solid organ transplant.

\section{INTRODUCTION}

Solid organ transplants remain the last possible recourse for some patients with organ failure. Transplants represent improvement in the quality of life for dialysis patients and those with other chronic disease states by offering them a second opportunity at life. Over 135,000 solid organ transplants were performed worldwide in 2016; over 34,000 of these were performed in the United States and there are more than 114,000 people are on the waiting list as of April $2018(1,2)$. The most common solid organ transplants are renal transplants followed by liver transplants. Unfortunately, transplants pose a high risk for infections which can be a major cause of morbidity and mortality among patients after transplantation. In fact, it is the second leading cause of death in patients with renal transplants (3). Those who undergo transplantation are highly susceptible to both bacterial and viral infections due to the immunosuppressive therapy which is used to prevent transplant rejection. Post-transplantation infections include those caused by Streptococcus pneumoniae, cytomegalovirus (CMV), Hepatitis C virus (HCV)

\footnotetext{
Address for Correspondence: Prashant Sakharkar, PharmD, $\mathrm{MPH}$, Associate Professor, Clinical and Administrative Sciences, Roosevelt University College of Pharmacy, $1400 \mathrm{~N}$ Roosevelt Blvd, Schaumburg, IL, (USA); Email: psakharkar@roosevelt.edu
} 
and BK polyomavirus. Renal and hepatic transplant graft survival is severely complicated by these infectious pathogens.

CMV infection is the most common opportunistic infection and is a major cause of posttransplant infection (4). CMV is a double stranded deoxyribonucleic acid (DNA) virus and mostly presents as a latent virus that can be reactivated posttransplantation. CMV occurs in $8-32 \%$ of renal transplant recipients. CMV disease was associated with an increased risk of graft rejection or loss (5). There are several risk factors that contribute to the development of CMV infection such as age, concomitant infections, immunosuppression, and genetic polymorphisms (4). The infection typically does not cause symptoms in its latent phase but may present flu-like symptoms in the host when reactivated and can affect many organs. Elevated liver enzymes, thrombocytopenia and leukopenia can occur in the host (4).

Similar to renal transplants, liver transplants are also susceptible to viral infection and subsequent allograft rejection. Viral hepatitis is characterized by inflammation of the liver, and its pathogenesis, disease progression, and treatment are influenced by cytokines. In the three major stages of hepatitis infection - namely acute, chronic, and cirrhosis cytokines play a prominent role in the first two stages when the disease is in the development and maintenance stage (6). Among the five types of hepatitis virus $(\mathrm{A}, \mathrm{B}, \mathrm{C}, \mathrm{D}, \mathrm{E})$, the main focus of cytokines is on HCV and HBV pathogenesis, graft survival or rejection, and treatment outcome. In patients who receive liver transplants with $\mathrm{HCV}$ recurrence, $10-20 \%$ of them develop cirrhosis within five years, compared to the general population who develop cirrhosis within twenty to thirty years (7). HBV can also cause liver cirrhosis and is a major public health concern due to risk of death. According to the World Health Organization, around 650,000 people will pass away due to complications associated with HBV (7).

Cytokines are a large class of proteins and are essential elements in both the adaptive and innate immune system and can affect cells in the body which mobilize and induce inflammation during infection (7). Interestingly, cytokines can have dual roles in the development and progression of viral infection in liver and kidney transplant patients. Certain proteins demonstrate anti-viral properties compared to others which facilitate immunemediated inflammatory effects. Similar to most viral infections, subsequent to HCV and HBV infections, the body attempts to clear the viral load through an immune response via cytokines such as interleukin (IL), tumor necrosis factor-alpha (TNF- $\alpha$ ) and interferon (IFN) (8). In the absence of appropriate cytokine functions, the HCV or HBV infections eventually lead to fibrogenesis of the liver and require a liver transplant. The success of a liver transplant is considerably dependent on the status of cytokine functions (8). Cytokines play an important role in $\mathrm{CMV}, \mathrm{HBV}$, and $\mathrm{HCV}$ infections, as well as triggering the induction of these cytokines during infection (9). There is evidence that cytokines have a protective role in CMV infections, as they produce IFN- $\lambda$ and IL, but cytokines also induce T-cells that cause chronic inflammation-related tissue damage if unregulated (9).

Different forms of cytokine genes arising from the variation in the DNA sequence or polymorphism can lead to altered functionality of cytokines, which in turn can differentially affect the development, progression, and treatment of viral infections (10). Single-nucleotide polymorphisms (SNP) in cytokines, which occur from changes in a single nucleotide base leading to altered protein and function, may be associated with a susceptibility to and an increased risk of infection and response to antiviral treatments (10). The role of cytokine gene polymorphisms and their associations with $\mathrm{CMV}$ infection have yet to be fully studied. The presence of these SNPs may predict a patient's outcome during post-transplantation. Further research is needed and exploration into these polymorphisms is essential in order to improve health outcomes in patients with solid organ transplants, such as renal and liver transplants, and other disease conditions. This is crucial in order to guide therapy and tailor drugs to a patient's genetic makeup in order to prevent complications from infections and to ensure graft and patient survival.

Several studies have broadly investigated the association of cytokine gene polymorphisms and different types of infections post solid organ transplant. However, there are limited studies that have systematically assessed the impact of cytokine polymorphisms on CMV infection in renal transplant recipients and $\mathrm{HBV}$ and $\mathrm{HCV}$ infection among liver transplant recipients. The aim of this study is to explore whether in renal and liver transplant recipients (population), are cytokine gene polymorphisms (Exposure/Non-exposure) associated with risk of $\mathrm{CMV}, \mathrm{HBV}$ and $\mathrm{HCV}$ 
infections (Outcomes) by using the Patient or Population, Intervention or Exposure, Comparison and Outcomes (PICO) framework. This review primarily focuses on systematically organizing and analyzing the association between cytokine gene polymorphism and $\mathrm{CMV}$ in renal transplant recipients and $\mathrm{HBV}$ and $\mathrm{HCV}$ in liver transplant recipients.

\section{METHODS}

\section{Data sources, search terms and inclusion criteria:}

A search was performed through Medline (up to January 2019), EMBASE (up to January, 2019), PubMed (up to January, 2019) and Google Scholar (up to January, 2019) to identify studies that examined the associations between cytokine gene polymorphisms and CMV in renal transplant and $\mathrm{HBV}$ and $\mathrm{HCV}$ in liver transplant recipients. The following keywords were used in the search "cytokine", "cytokine gene", "polymorphism", "polymorphism, genetic", "Cytomegalovirus", "Hepatitis B", "Hepatitis C", "Hepatitis", "viral infections", "renal transplantation", "kidney transplantation", "renal transplant", "liver transplantation", "liver transplant", "solid organ transplantation", "solid organ transplant" (Appendix S1). The last search was performed on January 28, 2019. At first, titles and abstracts were screened for their inclusion, followed by a screening of the full texts. Review articles, case reports or studies, studies conducted in other than human subjects, performed in other than renal and liver transplant recipients, and articles published in other than the English language were excluded.

\section{Data extraction}

Electronic database searches were performed by all authors. The two investigators (SB and PS) assessed the eligibility and quality of all studies included according to the predetermined selection criteria. Information was extracted independently by all authors from eligible publications using a data abstraction form which included the following: Authors, year of publication, country of origin, study design, sample size, genotype, polymorphisms and its impact on transplant outcome (post-transplant infection) (Appendix S2). Discrepancies between the investigators were discussed and resolved by consensus.

\section{Quality of publications}

The quality of publications was assessed using Risk of Bias Assessment Tool for Nonrandomized Studies (RoBANS). The RoBANS tool contains six domains, including the selection of participants, confounding variables, measurement of the intervention (exposure), blinding of the outcome assessment, incomplete outcome data, and selective outcome reporting (11). RoBANS is a validated tool that is reliable and feasible for the assessment of the methodological quality of non-randomized studies. Review Manager version 5.3.3 was used to generate a summary of the RoBANS results (12). Our review was designed and reported in accordance with the Preferred Reporting Items for Systematic Reviews and Meta-Analysis (PRISMA) checklist (13) (Appendix S3).

\section{RESULTS}

\section{Study characteristics:}

Our screening identified 73 potentially relevant articles. A total of 31 studies were included that met our inclusion criteria (Figure 1).

Nine studies explored the association of cytokine gene polymorphism and post-transplant CMV infection in renal transplant recipients, six studies assessed the association with $\mathrm{HBV}$ and 16 studies looked at its association with $\mathrm{HCV}$ infection post liver transplantation. Fourteen studies were from a European population, six studies were from Asian populations, and 11 studies were performed in a mixed population. Nineteen studies were performed to evaluate IL-28B polymorphism in renal and hepatic transplant patients, while 6 studies evaluated the association between IFN- $\lambda$ gene polymorphism and its impact on the progression of CMV, HCV, and HBV. Polymorphisms in IL-10 were investigated in six studies. The characteristics of the studies included are presented in Table 1. The quality assessment of included non-randomized studies based on RoBANS tool is presented in Table 2 . 

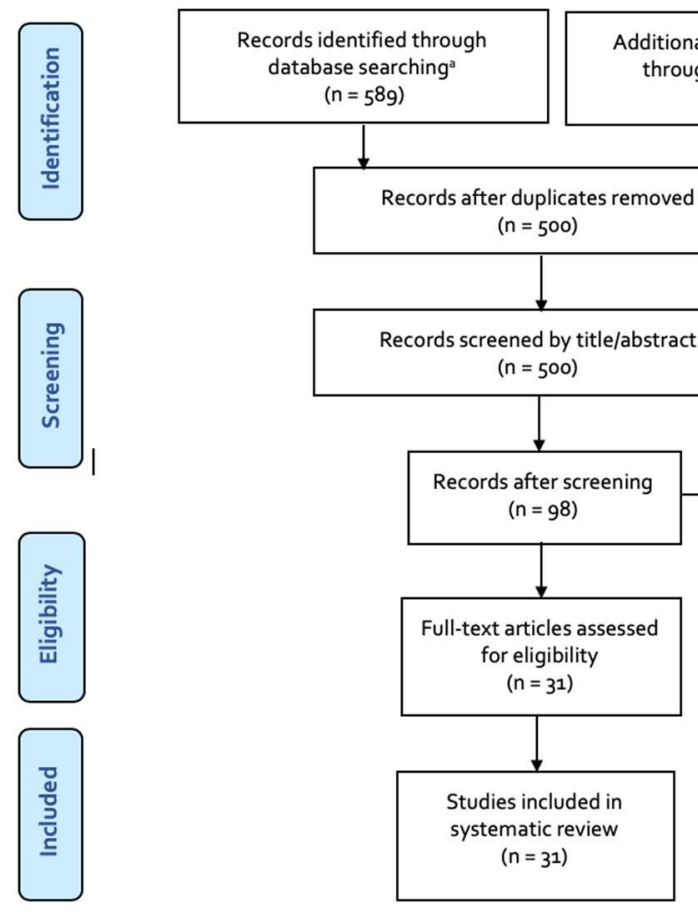

Records excluded $(n=402)$

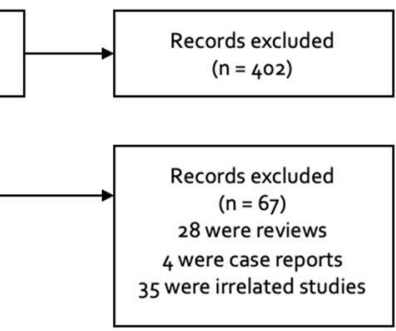

Figure 1. Flow diagram of identification, screening and inclusion of studies

Table 2. Quality assessment of included non-randomized studies based on RoBANS tool

\begin{tabular}{|c|c|c|c|c|c|c|}
\hline $\begin{array}{l}\text { Authors, } \\
\text { Year }\end{array}$ & $\begin{array}{l}\text { Selection of } \\
\text { Participants }\end{array}$ & $\begin{array}{l}\text { Confounding } \\
\text { Variables }\end{array}$ & $\begin{array}{l}\text { Intervention } \\
\text { Measurement }\end{array}$ & $\begin{array}{l}\text { Blinding of } \\
\text { Outcome } \\
\text { Assessment }\end{array}$ & $\begin{array}{l}\text { Incomplete } \\
\text { Outcome } \\
\text { Data }\end{array}$ & $\begin{array}{l}\text { Selective } \\
\text { Outcome } \\
\text { Reporting }\end{array}$ \\
\hline $\begin{array}{l}\text { Fernandez- } \\
\text { Ruiz M et al, } \\
2015\end{array}$ & + & & + & + & + & + \\
\hline $\begin{array}{l}\text { Manuel O et } \\
\text { al, } 2015\end{array}$ & + & & + & + & + & + \\
\hline $\begin{array}{l}\text { Santiago JL } \\
\text { et al, } 2018\end{array}$ & + & + & + & + & & + \\
\hline $\begin{array}{l}\text { Hoffmann T } \\
\text { et al, } 2008\end{array}$ & + & & + & + & + & + \\
\hline $\begin{array}{l}\text { Hoffmann T } \\
\text { et al, } 2010\end{array}$ & + & & + & + & + & + \\
\hline $\begin{array}{l}\text { Rodrigo E et } \\
\text { al, } 2007\end{array}$ & + & + & & + & + & + \\
\hline $\begin{array}{l}\text { Alakulppi N } \\
\text { et al, } 2006\end{array}$ & - & & + & + & + & + \\
\hline $\begin{array}{l}\text { Aguado et al, } \\
2018\end{array}$ & + & + & + & + & + & + \\
\hline $\mathrm{Vu}$ et al, 2014 & + & + & + & + & + & + \\
\hline $\begin{array}{l}\text { Allam et al, } \\
2013\end{array}$ & + & + & + & + & + & + \\
\hline $\begin{array}{l}\text { Lange et al, } \\
2011\end{array}$ & - & + & + & + & & + \\
\hline
\end{tabular}


Table 2. Quality assessment of included non-randomized studies based on RoBANS tool

\begin{tabular}{|c|c|c|c|c|c|c|}
\hline $\begin{array}{l}\text { Authors, } \\
\text { Year }\end{array}$ & $\begin{array}{l}\text { Selection of } \\
\text { Participants }\end{array}$ & $\begin{array}{l}\text { Confounding } \\
\text { Variables }\end{array}$ & $\begin{array}{l}\text { Intervention } \\
\text { Measurement }\end{array}$ & $\begin{array}{l}\text { Blinding of } \\
\text { Outcome } \\
\text { Assessment }\end{array}$ & $\begin{array}{l}\text { Incomplete } \\
\text { Outcome } \\
\text { Data }\end{array}$ & $\begin{array}{l}\text { Selective } \\
\text { Outcome } \\
\text { Reporting }\end{array}$ \\
\hline $\begin{array}{l}\text { Mueller JL et } \\
\text { al, } 2016\end{array}$ & + & + & + & + & + & + \\
\hline $\begin{array}{l}\text { Fernandez- } \\
\text { Carrillo C et } \\
\text { al, } 2014\end{array}$ & + & + & + & + & + & + \\
\hline $\begin{array}{l}\text { Barbera F et } \\
\text { al, } 2015\end{array}$ & + & + & + & + & + & + \\
\hline $\begin{array}{l}\text { Firpi RJ et al., } \\
2013\end{array}$ & + & + & + & + & + & + \\
\hline $\begin{array}{l}\text { Monaghan } \\
\text { KG et al, } \\
2015\end{array}$ & - & + & + & + & + & + \\
\hline $\begin{array}{l}\text { Cisneros E et } \\
\text { al, } 2013\end{array}$ & + & + & + & + & + & + \\
\hline $\begin{array}{l}\text { El Awady } \\
\text { MK et al, } \\
2014\end{array}$ & + & + & + & + & + & + \\
\hline $\begin{array}{l}\text { Kawaoka T et } \\
\text { al, } 2012\end{array}$ & + & + & + & + & + & + \\
\hline $\begin{array}{l}\text { Harada } N \text { et } \\
\text { al, } 2014\end{array}$ & + & + & + & + & + & + \\
\hline $\begin{array}{l}\text { Coto-Llerena } \\
\mathrm{M} \text { et al, } 2011\end{array}$ & + & + & + & + & + & + \\
\hline $\begin{array}{l}\text { Charlton MR } \\
\text { et al, } 2011\end{array}$ & + & + & + & + & + & + \\
\hline $\begin{array}{l}\text { Duarte-Rojo } \\
\text { A et al, } 2012\end{array}$ & + & + & + & + & + & + \\
\hline $\begin{array}{l}\text { Świątek- } \\
\text { Kościelna B } \\
\text { et al, } 2017\end{array}$ & + & + & + & + & + & + \\
\hline $\begin{array}{l}\text { Ge D et al, } \\
2009\end{array}$ & + & + & + & + & + & + \\
\hline $\begin{array}{l}\text { Li W et al, } \\
2012\end{array}$ & + & + & + & + & + & + \\
\hline $\begin{array}{l}\text { Li W et al, } \\
2011\end{array}$ & + & + & + & + & + & + \\
\hline $\begin{array}{l}\text { Li Y et al, } \\
2017\end{array}$ & + & + & + & + & + & + \\
\hline $\begin{array}{l}\text { Abbott et al, } \\
2007\end{array}$ & - & + & + & + & + & + \\
\hline $\begin{array}{l}\text { Ben-Ari Z et } \\
\text { al, } 2003\end{array}$ & - & + & & + & + & + \\
\hline $\begin{array}{l}\text { Chen et al, } \\
2016\end{array}$ & + & + & + & + & + & + \\
\hline
\end{tabular}

The studies included showed low risk of bias for both blinding for outcome assessment and selective outcome reporting domain of the tool in all of the studies, high risk of bias for selection of the participants and confounding variables domain in five studies and unsure risk of bias for intervention measurement and incomplete outcome data domain in two studies (Figure 2). 


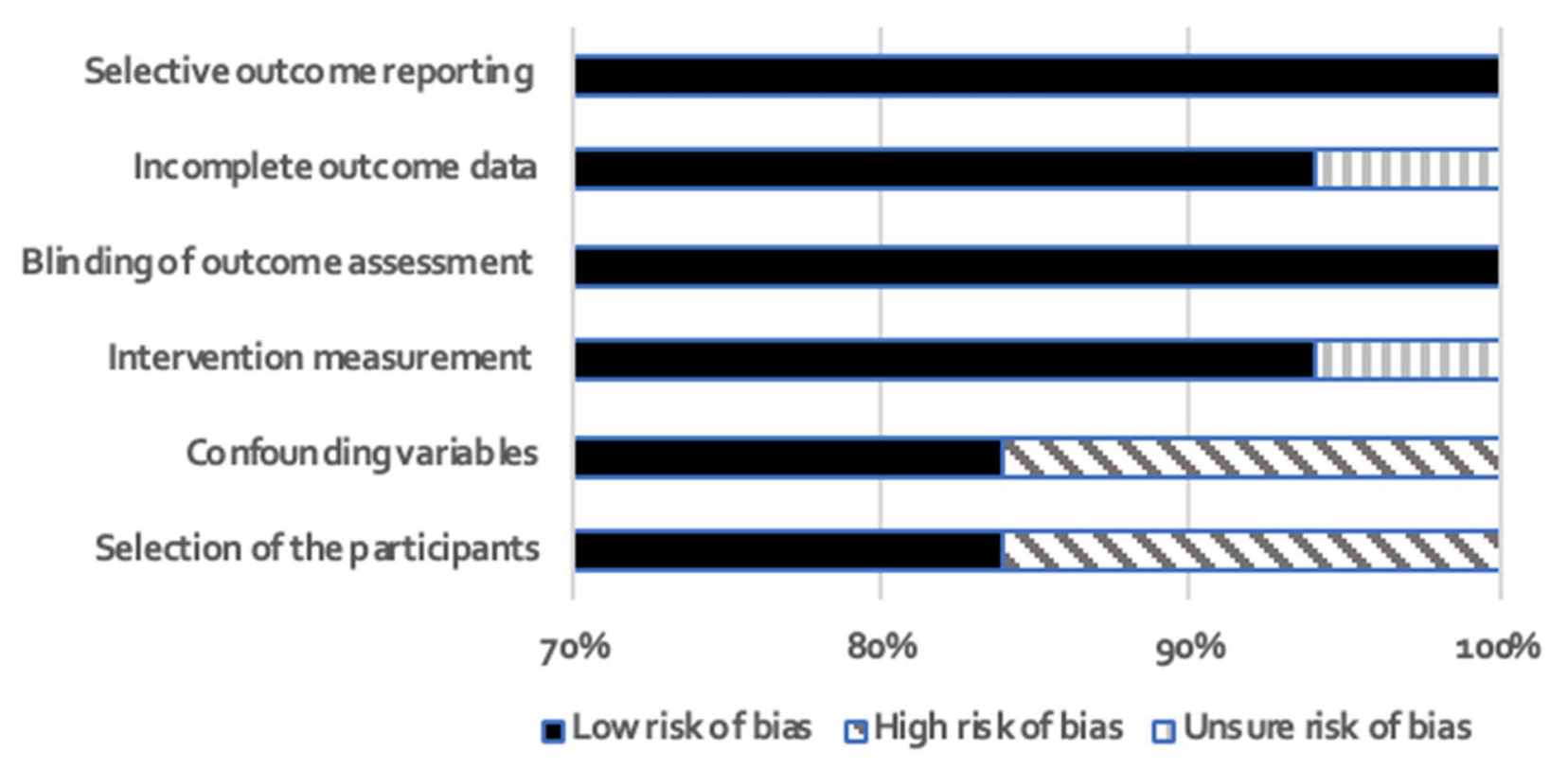

Figure 2. Summary of the methodological quality of all enrolled studies

\section{Role of Cytokines in Renal Transplant}

A lower incidence of CMV infection was found in patients with A-allele genotypes of toll like receptor 2 (TLR-2) and T-allele genotypes of IL-28B. Patients with the A-allele were less susceptible to CMV infection compared to patients with the GG genotype (14). The 12-month CMV infection free survival rate was $85 \%$, compared to $53 \%$ in patients with the GG genotype. The survival rate was also higher among patients with the TT genotype of TLR9 compared to those with the AA/AG genotypes of dendritic cell-specific ICAM 3-grabbing nonintegrin (DC-SIGN) SNP, 54\% compared to $40 \%$, respectively. This effect was found to be more pronounced in patients not on prophylaxis therapy and was also associated with a lower risk of CMV infection. This study concluded a significant relationship between the number of unfavorable SNP genotypes and the overall risk of CMV infection, specifically, SNPs in IL-28B, TLR-9, and DC-SIGN genes may have modulated the susceptibility to CMV infection in these patients (14).

In another study, the incidence of CMV replication emerged to be higher among recipients who were homozygous for the minor allele of rs368234815 (-G/-G carriers) compared with other patients (TT/TT or TT/-G carriers). The results of this study indicated that IFN- $\lambda$ rs368234815 polymorphism might be a risk factor for developing CMV associated complications post-renal transplantation (15). In a retrospective study conducted in Spain, 205 patients developed CMV infection and the median time to onset was 2.7 months (15). However, Santiago and colleagues found no association of IFN- $\lambda-874 \quad \mathrm{~A} / \mathrm{T}$ polymorphism as a predictive marker of CMV infection in their analyses (16). Previously, the Callele was found to be an independent risk factor for CMV infection on a multifactorial Cox regression analysis. This risk was estimated to be even higher in patients with a positive CMV serological status before the transplantation and who did not receive prophylaxis (17). Programmed cell death protein (PD)-1 is known to inhibit IFN- $\lambda$ production and has been reported to be clinically relevant in immune disorders. Forty six percent of those that were carriers of the A-allele acquired CMV infection. It has been hypothesized that the A-allele could affect PD-1 inhibition and increase inflammatory mediators post kidney transplantation (18). Hoffman and colleagues in this study further concluded that the A-allele was associated with risk of CMV infection in those who did not receive prophylaxis. In patients with PD-1.3, the A-allele had a much 
higher risk of CMV infection and prophylaxis based on genetic markers, which needs to be further researched (18).

Cytokine polymorphisms (IL-10, transforming growth factor beta (TGF-B), TNF- $\alpha$, IFN- $\lambda$, IL-6, IL4, IL-2, IL-4R, IL-12, IL-4RA, IL-1RA, IL-1R, IL$1 \mathrm{~B}$, and IL-1A) were studied to determine the relationship between cytokine polymorphisms and infection in kidney transplant recipients (19). A total of 122 patients developed at least one instance of infection within the first year. Female patients developed infections more than their male counterparts. Recipients with -511 IL-1B CC genotype or with -1188 IL-12 CA and CC genotypes were at higher risk of developing infections in the first year. These genotypes predicted the risk of posttransplantation infection in the first year after transplantation (19).

Seventy-one CMV seronegative recipients of grafts from CMV seropositive donors were studied in Finland where IL-10, IL-6, and IFN- $\lambda$ gene polymorphisms were explored for the links between these genes and infection. The donor IL-10 (-1082 AA) genotype reduced the incidence of CMV infection, suggesting that gene polymorphism may impact the likelihood of CMV infection in high risk patients (20). A lower risk of CMV reactivation in those with AA genotypes compared to AT genotypes of the IFN- $\lambda$ gene was predicted in a large sample in this Spanish study. No genotypes conferred a protective effect among polymorphisms in IL-28B. The authors found no differences between IFN- $\lambda$ levels in those with and without CMV replication and no differences between peak viral load, duration, or onset of replication due to a small sample size (21).

Patients with donor-positive/recipient-negative (D+/R-) serostatus were found to be associated with a high risk of CMV infection among Hispanic renal transplant recipients in this study by $\mathrm{Vu}$ et al (22). A significant association was found between IFN- $\gamma$ $+874 \mathrm{~A}>\mathrm{T}$ polymorphism and the risk of CMV infection. The IFN- $\gamma+874$ AA genotype was associated with a 3.4-fold increased risk for the CMV-infected group compared to the non-CMV group. Individuals with IFN- $\gamma+874$ AT and AA genotypes exhibited a higher risk of allograft loss. The results of this study suggested that renal transplant recipients with the variant homozygous IFN- $\gamma$ AA genotype were at risk of CMV infection, whereas the high producer IFN- $\gamma+874$ TT genotype appears to be associated with a lower risk of CMV infection (22).

\section{Cytokine Polymorphism and Hepatitis C Virus}

An investigation by Allum and colleagues indicated that liver transplant patients with a $\mathrm{CC}$ or $\mathrm{CT}$ genotype of IL-28B had a lesser chance of graft rejection compared to the TT genotype (62\% versus $48 \%$ ) (23). Interestingly, the positive influence of the $\mathrm{CC} / \mathrm{CT}$ genotype on reappearance of $\mathrm{HCV}$ and the potential of graft rejection were not reliant on antiviral treatment. The authors concluded that unlike the popular notion that donor IL-28B is a predictor of liver transplant success, the recipient's IL-28B status is actually more important in assessing the final outcome of graft survival (23). Similarly, the effect of IL-28B polymorphisms was evaluated in donor and recipient on graft survival during liver transplant. In a cohort of 91 patients with HCV reinfection after liver transplant, genotype rs12979860 CT/TT was identified as a predictor of HCV infection (24).

Allograft cirrhosis was developed in $20 \%$ of the patients. Recipients who received a liver from those with epidermal growth factor (EGF) non-AA alleles had an increased graft cirrhosis progression compared to those with an AA allele donor liver (25). An increased rate of sustained virologic response (SVR) was seen in the CC allele of IL-28B compared to non-CC alleles. However, no association was found between the recipient or donor IL-28B and patatin like phospholipase domain containing 3 (PNPLA3) genotype and adverse clinical outcomes (25). In another study, polymorphisms in the IFN- $\lambda 4$ res368234815 strongly influenced antiviral treatment response. After transplantation, recipient IFN- $\lambda 4$ genotype TT/TT was associated with a higher SVR rate (26). SVR occurred more in patients receiving a liver from a donor with a favorable genotype, however this result was found to be not statistically significant (26).

HCV RNA clearance induced by antiviral treatment was associated with the cytokine alleles. rs12979860 CC and rs12980275 AA genotype was associated with both end of therapy response (EOTR) and SVR while rs8099917 TT genotype was not associated with SVR but was significantly associated with EOTR (27). Homozygosis of the rs12979860 CC genotype was associated with a positive response to antiviral treatment, suggesting that analyzing IL-28B genotypes might be helpful in order to optimize HCV therapy (27). Patients who 
did not have the CC genotype of IL-28B but received an IL-28B CC donor liver were found to have a higher chance of achieving SVR than those who obtained a non-CC donor liver. Only $25 \%$ of patients achieved SVR if they did not have the CC allele from donor or recipient. Patients also had less fibrosis than recipients with CT and TT genotypes, however, this difference was found not statistically significant. Patient survival did not alter due to IL-28B polymorphism and only 3 patients had graft failures in this study (28). The donor or recipient with rs 12979860 CC was also found associated with an increased SVR who were undergoing antiviral treatment (29).

In a study with a Spanish patient cohort, posttransplantation $\mathrm{HCV}$ infection was influenced in recipients carrying IL-28B rs12979860 genotype. Forty patients developed severe HCV recurrence while 49 patients did not. It was statistically significant that more patients who had severe HCV recurrence had the TT allele and the T allele was associated with poor outcomes (30). The presence of the $\mathrm{T}$ allele in the liver donor had a lower risk of severe HCV recurrence, suggesting its more protective effect concluding that this genetic polymorphism can be a highly reliable predictive indicator of HCV reinfection (30). The authors suggested that the patients who have susceptible genotypes receive prophylactic antiviral treatment in order to improve health outcomes. In one small Egyptian study, IL-28B SNP and preoperative HCV titer predicted post-transplant HCV recurrence and disease-free survival (DFS) while genes in oligoadenylate synthase (OAS) and IL-1B had no association with DFS (30). Those with the CC genotype of IL-18B had higher rates of DFS after transplantation. Patients who had the IL-28B CT and TT alleles were more likely to develop $\mathrm{HCV}$ infection recurrence than those with the $\mathrm{CC}$ genotype. IL-1B polymorphism was not associated with $\mathrm{HCV}$ recurrence post transplantation (31).

The SVR rate was higher in donor grafts who had the TT genotype (73.3\%) compared to TG+ GG group $(20 \%)$ in this small Japanese study (32). Similar results were observed in another larger Japanese study where presence of the major allele (TT) in either the recipient or the donor was found to be associated with an SVR of $53 \%$ and $48 \%$, respectively. The minor allele (TG or GG) was found to be associated with an SVR of $26 \%$ and $32 \%$, respectively (33). On the other hand, SVR was determined to be higher in recipients with $\mathrm{CC}$ genotypes and when receiving grafts from $\mathrm{CC}$ genotype donors (34). Recipients with the TT and CT genotype had a shorter time to HCV recurrence within 5 years compared to the CC genotype, 100\%, $87 \%$, and $78 \%$, respectively in this study (35). Donor genotype was not found associated with time to recurrence. The rate of SVR was associated with the recipient and donor IL-28B genotype. Recipients with the CC or CT genotype had a higher SVR rate than those with the TT genotype, $58 \%, 47 \%, 0 \%$, respectively. Donors with the $\mathrm{CC}$ or CT genotype had similar rates. Rates were highest in those who had both matching donor and recipient CC genotype. Patients with the TT genotype or those who received a donor liver from a TT genotype did not attain SVR. Polymorphisms in IL-28B were predictive of fibrosis. Recipients with the TT genotype (32\%) had faster fibrosis formation after one year of transplantation (35). These results were also confirmed in a cohort study done in the United States among 255 patients that underwent liver transplantation with $\mathrm{HCV}$. Both recipient and donor CC genotype favored SVR (36).

Polymorphisms of IL-10 and their association with disease progression were investigated in a Polish patient cohort of 196 individuals (37). SNPs such as $1082(\mathrm{~A} / \mathrm{G})$ rs $1800896,819(\mathrm{C} / \mathrm{T})$ rs 1800871 , $592(\mathrm{C} / \mathrm{A})$ rs 1800872 and $+4529(\mathrm{~A} / \mathrm{G})$ rs3024498 in the promoter region of IL-10 gene were investigated. The abundance of ACCA, ATAA, GCCA and GCCG haplotypes were recognized in $>5 \%$ of individuals. The $\mathrm{C}$ allele of 592(C/A) SNP was related to liver inflammation and appeared to be protective, whereas ACCA and ACC haplotype were related to SVR and had lower potential to relapse (37). Genetic variations in the IL-28B gene were related to up to two-fold change in the treatment outcome in individuals with European ancestry and African-Americans. The formation and level of IFN$\lambda s$ were measured to be higher in hepatocytes of $\mathrm{HCV}$-inflicted patients and were associated with a positive IL-28B genotype and treatment outcome. For the rs12979860 genotypes, patients with two favorable response alleles (CC) had a higher probability of SVR to peginterferon alpha (PEGIFN- $\alpha$ ) and ribavirin (RBV) (38).

\section{Cytokine Polymorphism and Hepatitis B Virus}

In a cohort of $200 \mathrm{HBV}$ individuals, the SNPs of IL18 gene (rs187238 and rs1946518) and IL-28B (rs8099917) were studied in the Chinese Han population (39). The abundance of IL-18 SNPs was 
similar between recipient and donor in relapsing or non-relapsing HBV individuals. The authors found that the circulating IFN- $\lambda$ levels were lower in HBV patients with relapse history compared to the nonrelapsing patients (39). Interestingly, the IL-28B rs8099917 was associated with elevated alanine transaminase (ALT) and aspartate transaminase (AST) in HBV liver transplant individuals. Similarly, graft recipient individuals with allele G, and both the GG and GT genotypes, experienced elevated ALT and AST levels. The patients with genetic variants of IL-28B eventually had more hepatic dysfunction from HBV infection (39). The presence of SNPs of IL-28B (rs12979860, rs12980275, rs8099917) had a direct influence on serum ALT activity and the viral load in HBVinfected patients in the authors' previous investigation. There is strong evidence to suggest that rs8099917 $\mathrm{G}$ allele is a predictor of hepatic injury after liver transplantation and that patients with this variant should be observed for potential future relapse (40).

Lower platelet counts may be beneficial to HBVrelated recipients as it plays a role in liver recovery. Genetic variants of IL-28B may influence liver function recovery as the rs12979860 $\mathrm{T}$ allele and rs8099917 C allele have higher peripheral platelet counts after transplantation in the third and fourth day (41). IL-28B protective genotypes, rs 12979860 CC allele and rs8099917 AA allele, had significantly lower platelet levels in the first 4 days after transplantation. Abbott and colleagues reported two polymorphisms, namely, a microsatellite change in the +875 IFN $-\gamma$ CA Allele and a SNP in the +A874T, in the intron 1 of the IFN- $\gamma$ gene. Both of the variants have been attributed to elevated IFN- $\gamma$ formation which can lead to different clinical characteristics. In a study involving Polynesian women, the microsatellite and the SNP variants had a strong effect on unfolding innate immune responses in HBV patients (42). Similarly, a remarkable distinction was identified in the abundance of IFN- $\gamma$ polymorphisms between HBV-infected versus healthy patients (43). The authors did not observe any significant dissimilarity in the HBV infection outcomes due to TNF- $\alpha$, IL-6 and IL-10 polymorphisms (42). IL-6 gene polymorphism is another potential predictor of $\mathrm{HBV}$ prognosis, including hepatocellular carcinoma (HCC) (43). Chen and colleagues suggested that liver donors with rs2069852 AA variants are associated with HCC relapse and the reference SNP could work as a strong predictor of HCC relapse and shorter life expectancy following transplantation in the Chinese Han population (44).

\section{DISCUSSION}

Solid organ transplantations are a lifesaving procedure for those with chronic and end stage diseases and it can improve the quality of life of the recipient. However, there can be complications associated with transplants that further increase the risk of graft rejection, morbidity, and mortality for the patient. Risk factors such as age, immunosuppression and genetic composition can further complicate the development and progression of viral infection. In this review, we have investigated thirty-one studies related to various cytokine gene polymorphisms to determine if they influence $\mathrm{CMV}, \mathrm{HBV}$, and $\mathrm{HCV}$ infection risk in renal and liver transplant recipients. The results were consistent in demonstrating a relationship between cytokine gene polymorphisms and risk of viral infection. The findings of this systematic review suggest that gene polymorphism may be associated with a higher risk of viral infections, except in one instance when the cytokine variant form afforded lower risk of infection, in renal and liver transplant patients.

While eliciting the immune response, the cytokines can exert pro-inflammatory or antiinflammatory functions in organ recipients (7). In the context of the current work, IL-1B, IL-6, IL-12 and IL-18 have pro-inflammatory actions, whereas IFN$\lambda$-based genes (IL-28B) and IL-10 are antiinflammatory in nature. The IL-1B and IL-18 cytokines are involved in generating complex cytotoxic actions through inflammation. IL-10 is a master regulator of anti-inflammatory and immunosuppressive actions and provides a protective role in hepatic viral infections and posttransplant infections $(19,20)$. Whereas IL-28B is part of the cluster of genes known as type III interferons or IFN- $\lambda 3$, which is associated with comprehensive antiviral and cytotoxic actions (45).

In the patients who have undergone renal transplants, polymorphisms in IL-12, IL-1B, IFN- $\lambda$, and PD1 were associated with a higher risk of CMV infection. Individuals with $\mathrm{G} /-\mathrm{G}$ allele in the IFN- $\lambda$ cytokine were more prone to developing CMVassociated complications post-transplant. The $\mathrm{C}$ allele in the p40 gene of IL-12B was considered to be an independent risk factor for CMV infection in 
one study, especially in carriers who did not receive antiviral prevention therapy. The A allele was also associated with a higher risk of CMV in those who did not receive prophylaxis therapy. Patients who had the T-allele of IL-28B and carriers of TLR-9 SNP had lower incidences of CMV infection. Polymorphisms in IFN- $\lambda$ was also studied but it did not prove to be a predictive marker of $\mathrm{CMV}$ infection.

Polymorphisms in IL-28B were associated with both the risk of HCV disease pathogenesis and hepatic dysfunction from HBV infection in patients that underwent hepatic transplants. Three studies concluded that the CC genotype in IL-28B was associated with a greater rate of SVR compared to the TT genotype. The $-592 \mathrm{C}$ allele in IL-10 cytokine was associated with mild hepatic inflammation when compared to the A allele. Pharmacogenomics is an important aspect of $\mathrm{HCV}$ treatment where the genomic polymorphisms of cytokines dominate if an individual is a candidate for PEG-IFN- $\alpha$ and RBV treatment or not. Although, with the advent of newer small molecules drugs for HCV, the PEG-IFN and RBV are losing their place in the clinic. Nevertheless, a large number of $\mathrm{HCV}$ patients worldwide are still being treated with the interferonbased regimens.

Similar to HCV, the HBV virus can cause acute and chronic liver issues that can eventually require a liver transplant. Although the discussion on IL-10 started lately, there are few interesting observations about the role of this cytokine in HCV infections. IL18 is known to be a dominant inflammatory cytokine, which can fight with the HBV and remove it from the host (human) body. IL-18 is one of the cytokines that induces IFN- $\lambda$ and as a result IL-18 can provide protection from $\mathrm{HBV}$ infection. In addition, similar to HCV, IL-28B has a key role in the HBV disease development, progression and graft survival outcomes. Similarly, IFN- $\lambda$ is a protective cytokine and exerts a strong function on the treatment of HBV infection; the genetic variants of the IFN- $\lambda$ gene could be a crucial factor in the HBV disease timeline.

The carriers of cytokine polymorphisms demonstrate differential susceptibility to viral infection as well as response from antiviral treatment following liver or kidney transplants. Among the cytokine genes discussed in this study, polymorphisms of IL-28B have reached conclusive implications in the disease pathogenesis and clinical management of viral hepatitis. For the rs 12979860 polymorphism of the IL-28B gene, the individuals with the $\mathrm{CC}$ genotype had a better prognosis compared to CT or TT genotypes, which essentially drive the organ transplant recipients towards hepatic fibrosis $(27,28)$. It is plausible that CT or TT genotype carriers express IL-28B protein isoforms that are unable to activate the phosphorylation pathways, leading to removal of the protective effects of IL-28B. According to the guidelines of the Clinical Pharmacogenetics Implementation Consortium, patients with the CC genotype, compared to CT or TT genotypes, have a higher probability of positive treatment outcome from a shorter treatment regimen (24-28 weeks versus 48 weeks) with PEG-IFN- $\alpha$ and RBV (46). Similarly, though the mechanism of this effect is not clear, for the rs 8099917 of the IL-28B gene, the TT genotype is hepatoprotective and is considered more desirable for the antiviral treatment (29). Thus, IL-28B genotypes can serve as a robust indicator of therapeutic success in IFN-RBV based treatments of hepatic viral infection. Similarly, the carriers of IL10 polymorphisms $(-592 \mathrm{~A}$ or $-819 \mathrm{~T})$ demonstrated improved response to the IFN-RBV regimen (47). It is noteworthy to mention that the basal functions of both IL-28B and IL-10 are anti-inflammatory in nature. In comparison, the polymorphisms of proinflammatory cytokines such as IL-1B $(-511 \mathrm{CC})$ or IL-12 (-1188 CA and CC) actually increased the risk of developing infection in kidney transplant patients (19). We postulate that the variants of IL-1B or IL12 downregulate the NK cell activation and dampen $\mathrm{T}$ cell mediated cytotoxicity, which make the transplant patients more susceptible to viral infection.

Further studies are needed to determine a direct association between $\mathrm{CMV}, \mathrm{HBV}$ and $\mathrm{HCV}$ infections and cytokine polymorphisms. Additional analysis may improve patients' health outcomes and reduce further complications. In the future, immunosuppressive and antiviral therapy can be specifically tailored to patients undergoing transplantation based on cytokine polymorphisms to limit their infection risk. Since cytokines have dual roles of defense and inflammation in the viral infections, the use of antiviral and immunosuppressant medications or the type of medications in transplant patients can be heavily determined by the polymorphic status of their cytokines. The therapeutic outcome or adverse effect landscape of antivirals and immunosuppressants could be affected by the cytokine variant status of a 
particular patient. The new generation anti-HCV small molecules have become part of the routine treatment in the last five years and the studies on the effect of these cytokine polymorphisms on their small molecule treatment outcome is warranted.

The current study has several limitations. Several studies examined a small sample population and many did not establish statistical significance due to this. Another drawback was that multiple studies primarily examined Caucasian patients despite the genetic variance among different races. Only a handful of studies were multicenter, multinational, or both, thereby limiting the scope of their application. Heterogeneity of studies, a handful of studies with small sample size, and variability in clinical settings all limited our ability to perform a meta-analysis to assess the summary effect of association between cytokine gene polymorphisms and post-transplant $\mathrm{CMV}, \mathrm{HBV}$ and $\mathrm{HCV}$ infection.

\section{CONCLUSIONS}

In conclusion, our systematic review has demonstrated that cytokine gene polymorphisms, especially IL-12B and IL-1B, were found to be associated with an increased risk of infection in kidney transplant recipients and IL-28B in liver transplant recipients. These results further confirm the role of cytokine variants in assessing susceptibility to infections, treatment efficacy, and outcomes in renal and liver transplant recipients. It is important for researchers to continue exploring cytokine gene polymorphisms to better inform healthcare providers about their possible role and impact on health outcomes, especially in renal and liver transplant patients, as well as in patients with other disease conditions, to guide their treatment options. The presence of unfavorable SNPs in donor and recipient genotypes may predict a recipient's susceptibility to post-transplant complications. It is important to conduct genetic testing and analyze a patient's cytokine genetic makeup prior to transplantation of an organ from a donor to ensure a favorable genotype which may lead to optimized drug therapy, reduced costs, and better health outcomes.

\section{CONFLICT OF INTEREST}

Authors have no financial or any other conflict of interest to declare.

\section{REFERENCES}

1. Global Observatory on Donation and Transplantation. WHO-ONT [Internet]. 2016 [updated 2016; cited 2019 Feb 22]. Available from: http://www.transplant-observatory.org.

2. U.S. Government Information on Organ Donation and Transplantation. Organ Donation Statistics [Internet]. [updated 2019 July 22; cited 2019 Feb 22]. Available from: https://www.organdonor.gov/statisticsstories/statistics.html.

3. Awan AA, Niu J, Pan JS, Erickson KF, Mandayam S, Winkelmayer WC, et al. Trends in the Causes of Death among Kidney Transplant Recipients in the United States (1996-2014). Am J Nephrol, 2018; 6 :472-481. doi: 10.1159/000495081.

4. Azevedo LS, Pierrotti, LC, Abdala E, Costa SF, Strabelli TM, Campos SV, et al. Cytomegalovirus infection in transplant recipients. Clinics (Sao Paulo), 2015; 70(7): 515-23. 10.6061/clinics/2015(07)09.

5. Santos CA, Brennan DC, Fraser VJ, Olsen MA. Delayed-onset cytomegalovirus disease coded during hospital readmission after kidney transplantation. Transplantation, 2014; $\quad 98(2)$ : $187-$ 94. doi: 10.1097/TP.0000000000000030.

6. Rehermann B. Pathogenesis of chronic viral hepatitis: differential roles of $\mathrm{T}$ cells and NK cells. Nat Med, 2013; 19(7): 859-68. doi: 10.1038/nm.3251.

7. DiPiro JT, Talbert R, Yee G, Matzke G, Wells BG, Posey M. Pharmacotherapy: A Pathophysiologic Approach. $10^{\text {th }}$ ed. United States: McGraw-Hill Education; 2017.

8. Koziel MJ. Cytokines in viral hepatitis. Semin Liver Dis, 1999; 19(2): 157-69. doi: 10.1055/s-20071007107.

9. Clement M, Humphreys IR. Cytokine-Mediated Induction and Regulation of Tissue Damage During Cytomegalovirus Infection. Front Immunol, 2019; 10: 78. doi: 10.3389/fimmu.2019.0007.

10. Loeffler J, Steffens M, Arlt EM, Toliat MR, Mezger $\mathrm{M}$, Suk A, et al. Polymorphisms in the Genes Encoding Chemokine Receptor 5, Interleukin-10, and Monocyte Chemoattractant Protein 1 Contribute to Cytomegalovirus Reactivation and Disease after Allogenic Stem Cell Transplantation. J Clin Microbiol, 2006; 44(5): 1847-50. doi: 10.1128/JCM.44.5.1847-1850.2006.

11. Kim SY, Park JE, Lee YJ, Seo HJ, Sheen SS, Hahn $\mathrm{S}$, et al. Testing a tool for assessing the risk of bias for nonrandomized studies showed moderate reliability and promising validity. J Clin Epidemiol, 2013; 66(4): 408-14. doi: 10.1016/j.jclinepi.2012.09.016.

12. Review Manager (RevMan) [Computer program]. Version 5.3. Copenhagen: The Nordic Cochrane Centre, The Cochrane Collaboration, 2014. 
13. Moher D, Liberati A, Tetzlaff J, Altman DG. The PRISMA Group. Preferred Reporting Items for Systematic Reviews and Meta-Analyses: The PRISMA Statement. PLoS Med, 2009; 6(7): e1000097. doi:10.1371/journal.pmed1000097.

14. Fernandez-Ruiz M, Corrales I, Arias M, Campistol JM, Gimenez E, Crespo J, et al. Association Between Individual and Combined SNPs in Genes Related to Innate Immunity and Incidence of CMV Infection in Seropositive Kidney Transplant Recipients: SNPs and CMV Infection in R+ KT Recipients. Am J Transplant, 2015; 15(5): 1323-35. doi: 10.1111/ajt.13107.

15. Manuel O, Wójtowicz A, Bibert S, Mueller NJ, van Delden C, Hirsch HH, et al. Influence of IFNL3/4 Polymorphisms on the Incidence of Cytomegalovirus Infection After Solid-Organ Transplantation. J Infect Dis, 2015; 211(6): 906-14. doi: 10.1093/infdis/jiu557.

16. Santiago JL, Pérez-Flores I, Sánchez-Pérez L, Higuera MAM, Querol-Garcia J, Romero NC, et al. Effect of Interferon-Gamma Gene Polymorphism $+874 \mathrm{~A} / \mathrm{T}$ on Cytomegalovirus Infection in Kidney Transplant Recipients with and without Prophylactic Treatment with Valganciclovir. Transplantation, 2018;102: S1. 10.1097/01.tp.0000543462.49681.cb.

17. Hoffmann TW, Halimi JM, Büchler M, VelgeRoussel F, Goudeau A, Al Najjar A, et al. Association Between a Polymorphism in the IL-12p40 Gene and Cytomegalovirus Reactivation After Kidney Transplantation. Transplantation, 2008; 85(10): 1406-11. doi: 10.1097/TP.0b013e31816c7dc7.

18. Hoffmann T, Halimi JM, Büchler M, Velge-Roussel F, Goudeau A, Al Najjar A et al. Association between a polymorphism in the human programmed death-1 (PD-1) gene and cytomegalovirus infection after kidney transplantation. J Med Genet, 2010; 47(1): 548. doi: 10.1136/jmg.2009.068841.

19. Rodrigo E, Sánchez-Velasco P, Ruiz J, FernándezFresnedo G, Lopez-Hoyos M, Pinera C, et al. Cytokine Polymorphisms and Risk of Infection After Kidney Transplantation. Transplant Proc, 2007; 39(7): 2219-21. doi: 10.1016/j.transproceed.2007.06.051

20. Alakulppi NS, Kyllönen LE, Salo HM, Partanen J, Salmela KT, Laine JT. The Impact of Donor Cytokine Gene Polymorphisms on the Incidence of Cytomegalovirus Infection After Kidney Transplantation. Transpl Immunol, 2006; 16(3-4): 258-62. doi: 10.1016/j.trim.2006.09.007.

21. Aguado, R, Páez-Vega A, Agüera ML, Montejo M, Guirado L, Fortun J, et al. Lack of evidence of association between IFNG and IL28B polymorphisms and QuantiFERON-CMV test results in seropositive transplant patients. Hum
Immunol, 2018; 79(6): 499-505. doi: 10.1016/j.humimm.2018.03.009.

22. Vu D, Shah T, Ansari J, Sakharkar P, Yasir Q, Naraghi R, et al. Interferon-gamma gene polymorphism $+874 \mathrm{~A} / \mathrm{T}$ is associated with an increased risk of cytomegalovirus infection among Hispanic renal transplant recipients. Transpl Infect Dis, 2014; 16: 724-732. doi: 10.1111/tid.12285.

23. Allam SR, Krüger B, Mehrotra A, Schiano T, Schröppel B, Murphy B. The association of IL28B polymorphism and graft survival in patients with hepatitis C undergoing liver transplantation. PLoS One, 2013; 8(1): e54854. doi: 10.1371/journal.pone.0054854.

24. Lange CM, Moradpour D, Doehring A, Lehr HA, Müllhaupt B, Bilbert S, et al. Impact of donor and recipient IL28B rs 12979860 genotypes on hepatitis C virus liver graft reinfection. J Hepatol, 2011; 55(2): 322-7. doi: 10.1016/j.jhep.2010.10.037.

25. Mueller JL, King LY, Johnson KB, Gao T, Nephew LD, Kothari D, et al. Impact of EGF, IL28B, and PNPLA3 polymorphisms on the outcome of allograft hepatitis C: a multicenter study. Clin Transplant, 2016; 30(4): 452-60. doi: 10.1111/ctr.12710.

26. Fernández-Carrillo $C$, Coto-Llerena $M$, González $P$, Crespo G, Mensa L, Caro-Perez N, et al. IFNL4 polymorphism predicts response to hepatitis $\mathrm{C}$ treatment after liver transplantation. J Clin Virol, 2014; 61(2): 282-85. doi: 10.1016/j.jcv.2014.07.015.

27. Barbera F, Russelli G, Pipitone L, Pietrosi G, Corsale S, Vizzini G, et al. IL28B polymorphisms of both recipient and donor cooperate to influence IFN treatment response in $\mathrm{HCV}$ recurrence after liver transplantation, but IL28B SNPs of the recipient play a major role in IFN-induced blocking of $\mathrm{HCV}$ replication. New Microbiol, 2015; 38(2): 201-10.

28. Firpi RJ, Dong H, Clark VC, Soldevilla-Picco C, Morelli G, Cabrera R, et al. CC Genotype Donors for the Interleukin-28B Single-Nucleotide Polymorphism are Associated with Better Outcomes in Hepatitis C after Liver Transplant. Liver Int, 2013; 33(1): 72-78. doi: 10.1111/liv.12013.

29. Monaghan KG, Gonzalez HC, Levin AM, Abouljoud MS, Gordon SC. Post-transplant course of hepatitis C after living donor liver transplantation in association with polymorphisms near IFNL3. J Interferon Cytokine Res, 2015; 35(4): 313-6. doi: 10.1089/jir.2014.0111.

30. Cisneros E, Baños I, Citores MJ, Duca A, Salas C, Noblejas A, et al. Increased risk of severe hepatitis C virus recurrence after liver transplantation in patients with a $\mathrm{T}$ allele of IL28B rs12979860. Transplantation, 2012; 94(3): 275-80. doi: 10.1097/TP.0b013e31825668f6.

31. El Awady MK, Bader El Din NG, Abdel Aziz Riad M, Omran MH, Abdelhafez TH, Elbaz TM, et al. Predictors of disease recurrence post living donor 
liver transplantation in end stage chronic $\mathrm{HCV}$ patients. Dis Markers, 2014; 2014: 202548. doi: $10.1155 / 2014 / 202548$.

32. Kawaoka T, Takahashi S, Takaki S, Hiramatsu A, Waki K, Hiraga N, et al. Interleukin-28B single nucleotide polymorphism of donors and recipients can predict viral response to pegylated interferon/ribavirin therapy in patients with recurrent hepatitis $\mathrm{C}$ after living donor liver transplantation. $\mathrm{J}$ Gastroenterol Hepatol, 2012; 27(9): 1467-72. doi: 10.1111/j.1440-1746.2012.07129.x.

33. Harada N, Tamura S, Sugawara Y, Togashi J, Ishizawa $\mathrm{T}$, Kaneko $\mathrm{J}$, et al. Impact of donor and recipient single nucleotide polymorphisms of IL28B rs8099917 in living donor liver transplantation for hepatitis C. PLoS One, 2014; 9(3): e90462. doi: 10.1371/journal.pone.0090462.

34. Coto-Llerena M, Pérez-Del-Pulgar S, Crespo G, Carrion JA, Martinez SM, Sanchez-Tapias JM, et al. Donor and recipient IL28B polymorphisms in HCVinfected patients undergoing antiviral therapy before and after liver transplantation. Am J Transplant, 2011; 11(5): 1051-7. doi: 10.1111/j.16006143.2011.03491.x.

35. Charlton MR, Thompson A, Veldt BJ, Watt BJ, Watt $\mathrm{K}$, Tillmann $\mathrm{H}$, et al. Interleukin-28B polymorphisms are associated with histological recurrence and treatment response following liver transplantation in patients with hepatitis $\mathrm{C}$ virus infection. Hepatology, 2011; 53(1): 317-24. doi: 10.1002/hep.24074.

36. Duarte-Rojo A, Veldt BJ, Goldstein DD, Tilman HL, Watt KD, Heimbach JK, et al. The course of posttransplant hepatitis $\mathrm{C}$ infection: comparative impact of donor and recipient source of the favorable IL28B genotype and other variables. Transplantation, 2012; 94(2): 197-203. doi: 10.1097/TP.0b013e3182547551.

37. Świątek-Kościelna B, Kałużna E, Strauss E, Januszkiewicz-Lewandowska D, Bereszynska I, Wysocki J, et al. Interleukin 10 gene single nucleotide polymorphisms in Polish patients with chronic hepatitis C: Analysis of association with severity of disease and treatment outcome. Hum Immunol, 2016; 78(2): 192-200. doi: 10.1016/j.humimm.2016.10.015.

38. Ge D, Fellay J, Thompson AJ, Simon JS, Shianna $\mathrm{KV}$, Urban TJ, et al. Genetic variation in IL28B predicts hepatitis $\mathrm{C}$ treatment-induced viral clearance. Nature, 2009; 461(7262): 399-401. doi: 10.1038/nature08309.

39. Li Y, Shi Y, Chen J, Cai B, Ying B, Wang L. Association of polymorphisms in interleukin-18 and interleukin-28B with hepatitis B recurrence after liver transplantation in Chinese Han population. Int $\mathbf{J}$ Immunogenet, 2012; 39(4): 346-52. doi: 10.1111/j.1744-313X.2012.01097.x.
40. Li W, Jiang Y, Jin Q, Shi X, Jin J, Gao Y. Expression and gene polymorphisms of interleukin 28B and hepatitis B virus infection in a Chinese Han population. Liver Int, 2011; 31(8): 1118-26. doi: 10.1111/j.1478-3231.2011.02507.x.

41. Li Y, Wei T, Yan L, Huang Q, Shi Y, Wang L. Association of interleukin-28B polymorphisms with platelet count and liver function recovery after liver transplant. Medicine (Baltimore), 2017; 96(44): e8219. doi: 10.1097/MD.0000000000008219.

42. Abbott W, Gane E, Winship I, Munn S, Tukuitonga C. Polymorphism in intron 1 of the interferon-gamma gene influences both serum immunoglobulin $\mathrm{E}$ levels and the risk for chronic hepatitis B virus infection in Polynesians. Immunogenetics, 2007; 59(3): 187-95. doi: 10.1007/s00251-006-0184-4.

43. Ben-Ari Z, Mor E, Papo O, Kfir B, Sulkes J, Tambur AR, Tur-Kaspa R, et al. Cytokine gene polymorphisms in patients infected with hepatitis B virus. Am J Gastroenterol, 2003; 98(1): 144-50. doi: 10.1111/j.1572-0241.2003.07179.x.

44. Chen D, Liu S, Chen S, Wang Z, Wu Z, Ma K, Fan J, et al. Donor interleukin 6 gene polymorphisms predict the recurrence of hepatocellular carcinoma after liver transplantation. Int J Clin Oncol, 2016; 21(6): 1111-1119. doi: 10.1007/s10147-016-1001-1.

45. De Re V, Gragnani L, Fognani E, Piluso A, Izzo F, Mangia A, et al. Impact of immunogenetic IL28B polymorphism on natural outcome of $\mathrm{HCV}$ infection. Biomed Res Int, 2014; 710642. doi:10.1155/2014/710642.

46. Muir AJ, Gong L, Johnson SG, Lee MT, Williams MS, Klein TE, et al. Clinical Pharmacogenetics Implementation Consortium (CPIC) guidelines for IFNL3 (IL28B) genotype and PEG interferon- $\alpha-$ based regimens. Clin Pharmacol Ther, 2014;95(2):141-46. doi:10.1038/clpt.2013.203.

47. Yee LJ, Tang J, Gibson AW, Kimberly R, Van Leeuwen DJ, Kaslow RA. Interleukin 10 polymorphisms as predictors of sustained response in antiviral therapy for chronic hepatitis $\mathrm{C}$ infection. Hepatology, 2001;33(3):708-12. 


\section{APPENDIX}

\section{S1: Search strategy used for PubMed}

\#1 - Cytokine [tiab] OR cytokine gene [tiab] OR "Cytokines" [MeSH]

\#2 - polymorphism [tiab] OR genetic polymorphism*[tiab] OR "Polymorphism, genetic" [MeSH]

\#3 - 1 AND 2

\#4 - viral infection*[tiab] OR cytomegalovirus*[tiab] OR "cytomegalovirus"[MeSH] OR hepatitis [tiab] OR hepatitis virus*[tiab] OR "hepatitis c"[MeSH] OR "hepatitis b" [MeSH]

\#5- solid organ transplant*[tiab] OR solid organ transplantation*[tiab] OR renal transplant*[tiab] OR renal transplantation*[tiab] OR "kidney transplantation" [MeSH] OR liver transplant*[tiab] OR liver transplantation*[tiab] OR "liver transplantation" $[\mathrm{MeSH}]$

\#6 - \#3 AND \#4 AND \#5

\section{S2: Content of data abstraction form used}

1. Title

2. Author(s)

3. Year of publication

4. Citation

5. Publication type

6. Country of origin

7. Study type

8. Selection of Participant

9. Blinding

10. Sample size, number in control/intervention group

11. Ethnicity

12. Cytokine gene explored

13. Allele/Polymorphism/SNPs reported

14. Intervention

15. Comparison

16. Post-transplant outcomes (CMV, HBV, HCV infection)

17. Measures of association and statistical significance reported (OR, HR, SVR, p-value etc.)

18. Study limitations stated

19. Comments/Remarks if any 
Table 1. Characteristics of the studies included and association of cytokine gene polymorphisms and viral infections in renal and liver transplant recipients

\begin{tabular}{|c|c|c|c|c|c|c|c|c|}
\hline $\begin{array}{l}\text { Authors and } \\
\text { Year of } \\
\text { Publication } \\
\end{array}$ & $\begin{array}{l}\text { Country of } \\
\text { Origin }\end{array}$ & Study Design & $\begin{array}{l}\text { Sample } \\
\text { Size }\end{array}$ & Ethnicity & $\begin{array}{l}\text { Cytokine } \\
\text { Gene }\end{array}$ & $\begin{array}{l}\text { Allele/Polymorphism/ } \\
\text { SNPs }\end{array}$ & $\begin{array}{l}\text { Intervention/ } \\
\text { Comparison }\end{array}$ & $\begin{array}{l}\text { Impact on Post-transplant } \\
\text { Outcome (Infection) }\end{array}$ \\
\hline $\begin{array}{l}\text { Fernandez- } \\
\text { Ruiz M et al., } \\
2015\end{array}$ & Spain & Cohort & 315 & $\begin{array}{l}93 \% \\
\text { Caucasian } \\
6 \% \text { African } \\
1 \% \text { Asian }\end{array}$ & $\begin{array}{l}\text { IL-10, } \\
\text { CCR-5, } \\
\text { TLR-2, } \\
\text { TLR-9, } \\
\text { DC-SIGN, } \\
\text { MCP-1, } \\
\text { IL-28B }\end{array}$ & $\begin{array}{l}\text { A-allele, T-allele, GG, } \\
\text { TT, AA, AG, CT, TT }\end{array}$ & $\begin{array}{l}\text { 12-month } \\
\text { cumulative } \\
\text { incidence of } \\
\text { laboratory- } \\
\text { confirmed CMV } \\
\text { infection (either } \\
\text { asymptomatic } \\
\text { infection or } \\
\text { CMV disease) } \\
\text { was assessed. }\end{array}$ & $\begin{array}{l}\text { IL-28B, TLR-9, and DC-SIGN } \\
\text { genes might modulate the } \\
\text { susceptibility to CMV } \\
\text { infection. Patients with T- } \\
\text { allele genotypes of IL-28B } \\
\text { SNP had lower incidence of } \\
\text { CMV infection (aHR: } 0.66 \text { ). } \\
\text { Carriers of TLR-9 SNP also } \\
\text { had lower incidence of } \\
\text { infection (aHR: } 0.61 \text { ) in renal } \\
\text { transplant patients. }\end{array}$ \\
\hline $\begin{array}{l}\text { Manuel O et } \\
\text { al., } 2015\end{array}$ & Switzerland & Cohort & 840 & Caucasian & IFN- $\lambda$ & $\begin{array}{l}\text {-G/-G, TT/TT, TT/-G } \\
\text { carriers }\end{array}$ & $\begin{array}{l}\text { Patients with - } \\
\text { G/-G allele vs } \\
\text { other patients } \\
\text { (TT/TT or TT/- } \\
\text { G) }\end{array}$ & $\begin{array}{l}\text { IFN- } \lambda \text { rs } 368234815(-\mathrm{G} /-\mathrm{G}) \\
\text { polymorphism might be a risk } \\
\text { factor for developing CMV- } \\
\text { associated complications post } \\
\text { renal transplantation. }\end{array}$ \\
\hline $\begin{array}{l}\text { Santiago JL et } \\
\text { al., } 2018\end{array}$ & Spain & $\begin{array}{l}\text { Retrospective } \\
\text { cohort }\end{array}$ & 600 & Spanish & IFN- $\gamma$ & $+874 \mathrm{~A} / \mathrm{T}$ & $\begin{array}{l}\text { Patients with AT } \\
\text { allele vs AA or } \\
\text { TT }\end{array}$ & $\begin{array}{l}\text { Found no association of IFN- } \gamma \\
874 \mathrm{~A} / \mathrm{T} \text { polymorphism as a } \\
\text { predictive marker of CMV } \\
\text { infection in the analyses (HR: } \\
1.30, \mathrm{p} \text { value: } 0.81 \text { ) in renal } \\
\text { transplant patients. }\end{array}$ \\
\hline $\begin{array}{l}\text { Hoffmann T } \\
\text { et al., } 2008\end{array}$ & Switzerland & $\begin{array}{l}\text { Retrospective } \\
\text { cohort }\end{array}$ & 469 & Caucasian & IL-12B & p40 gene & $\begin{array}{l}\mathrm{C} \text { allele carriers } \\
\text { vs } \mathrm{A} / \mathrm{A} \text { allele } \\
\text { carriers }\end{array}$ & $\begin{array}{l}\text { The C allele was an } \\
\text { independent risk factor for } \\
\text { CMV infection (OR: } 1.52, \mathrm{p} \text { : } \\
0.043 \text { ) especially in patients } \\
\text { who did not receive } \\
\text { prophylaxis and had a positive } \\
\text { CMV serological status before } \\
\text { renal transplantation (OR: } \\
1.88, \text { p: } 0.028)\end{array}$ \\
\hline $\begin{array}{l}\text { Hoffmann T } \\
\text { et al., } 2010\end{array}$ & Switzerland & $\begin{array}{l}\text { Retrospective } \\
\text { cohort }\end{array}$ & 469 & Caucasian & PD-1 & Intron 4 gene (PD-1.3) & $\begin{array}{l}\text { A allele carriers } \\
\text { vs } \mathrm{G} / \mathrm{G} \text { allele } \\
\text { carriers }\end{array}$ & $\begin{array}{l}\text { A allele was associated with a } \\
\text { higher risk of CMV in } \\
\text { seropositive patients who did } \\
\text { not receive prophylaxis }\end{array}$ \\
\hline
\end{tabular}


Table 1. Characteristics of the studies included and association of cytokine gene polymorphisms and viral infections in renal and liver transplant recipients

\begin{tabular}{|c|c|c|c|c|c|c|c|c|}
\hline $\begin{array}{l}\text { Authors and } \\
\text { Year of } \\
\text { Publication }\end{array}$ & $\begin{array}{l}\text { Country of } \\
\text { Origin }\end{array}$ & Study Design & $\begin{array}{l}\text { Sample } \\
\text { Size }\end{array}$ & Ethnicity & $\begin{array}{l}\text { Cytokine } \\
\text { Gene }\end{array}$ & $\begin{array}{l}\text { Allele/Polymorphism/ } \\
\text { SNPs }\end{array}$ & $\begin{array}{l}\text { Intervention/ } \\
\text { Comparison }\end{array}$ & $\begin{array}{l}\text { Impact on Post-transplant } \\
\text { Outcome (Infection) }\end{array}$ \\
\hline $\begin{array}{l}\text { Rodrigo E et } \\
\text { al., } 2007\end{array}$ & Spain & $\begin{array}{l}\text { Retrospective } \\
\text { cohort }\end{array}$ & 255 & Spanish & $\begin{array}{l}\text { IL-10, } \\
\text { TGF-B } \\
\text { TNF- } \alpha \\
\text { IFN- } \gamma \\
\text { IL-6, IL-4, } \\
\text { IL-2, IL- } \\
4 R, \text { IL-12, } \\
\text { IL-4RA, } \\
\text { IL-1RA, } \\
\text { IL-1R, IL- } \\
1 B \text {, and IL- } \\
1 \mathrm{~A}\end{array}$ & $\begin{array}{l}\text { CC, CT, TT alleles of } \\
\text { IL-1B, AA, CA, CC } \\
\text { alleles of IL-12, C, CT, } \\
\text { TT alleles of TGF-B 10, } \\
\text { CC, GC, GG alleles of } \\
\text { TGF-B } 25, \text { AA, GA, GG } \\
\text { alleles of TNF- } \alpha, \text { GG, } \\
\text { GT, TT alleles of IL-4 }\end{array}$ & $\begin{array}{l}\text { Appearance and } \\
\text { number of } \\
\text { infections within } \\
\text { the first year } \\
\text { after transplantat } \\
\text { ion were } \\
\text { identified }\end{array}$ & $\begin{array}{l}\text { therapy (OR: } 2.60, \mathrm{p}: 0.006) \text { in } \\
\text { renal transplant patients. } \\
\text { Recipients with }-511 \mathrm{IL}-1 \mathrm{~B} \\
\text { CC genotype or with }-1188 \\
\text { IL-12 CA and CC genotypes } \\
\text { were at higher risk of } \\
\text { developing CMV infections in } \\
\text { the first year (RR: } 2.67, \mathrm{p} \text { : } \\
0.007 \text { and RR: } 2.57, \mathrm{p}: 0.012 \text {, } \\
\text { respectively) in renal } \\
\text { transplant recipients. }\end{array}$ \\
\hline $\begin{array}{l}\text { Alakulppi } \mathrm{N} \\
\text { et al., } 2006\end{array}$ & Finland & Cohort & 71 & Finnish & $\begin{array}{l}\text { IL-10, IL-6, } \\
\text { and IFN- } \gamma\end{array}$ & $\begin{array}{l}\text { Alleles of IL-10, IL-6, } \\
\text { and IFN- } \gamma\end{array}$ & $\begin{array}{l}\text { AA genotype vs } \\
\text { other alleles }\end{array}$ & $\begin{array}{l}\text { Recipient polymorphisms did } \\
\text { not reduce CMV infection } \\
\text { incidences. Donor IL-10 (- } \\
1082 \text { AA) genotype reduced } \\
\text { the incidence of CMV } \\
\text { infection in renal transplant } \\
\text { patients. (HR: } 0.3, \text { p: } 0.043)\end{array}$ \\
\hline $\begin{array}{l}\text { Aguado et al., } \\
2018\end{array}$ & Spain & $\begin{array}{l}\text { Retrospective } \\
\text { cohort }\end{array}$ & 184 & Spanish & $\begin{array}{l}\text { IFN- } \gamma \\
\text { IL-28B }\end{array}$ & $\begin{array}{l}\mathrm{T} \& \mathrm{~A} \text { allele of IFN- } \gamma \\
\text { and } \mathrm{C} \& \mathrm{~T} \text { allele of IL- } \\
28 \mathrm{~B}\end{array}$ & $\begin{array}{l}\text { IFN- } \gamma: \text { TT vs } \\
\text { AT, AA vs AT } \\
\text { IL-28B: CC vs } \\
\text { CT, TT vs CT }\end{array}$ & $\begin{array}{l}\text { Polymorphisms did not have } \\
\text { any impact on the risk of } \\
\text { CMV replication after renal, } \\
\text { lung and liver transplantation. } \\
\text { They observed a lower risk of } \\
\text { CMV reactivation in those } \\
\text { with AA genotype compared } \\
\text { to AT genotypes of the IFN- } \\
\text { gamma gene IFN- } \gamma \text { (OR: } 0.42 \text {, } \\
\text { p: } 0.051) \text {. }\end{array}$ \\
\hline $\begin{array}{l}\text { Vu et al., } \\
2014\end{array}$ & United States & $\begin{array}{l}\text { Retrospective } \\
\text { Cohort }\end{array}$ & 247 & Hispanic & $\begin{array}{l}\text { IL- } 10 \\
\text { TNF- } \alpha \\
\text { IFN- } \gamma\end{array}$ & $\begin{array}{l}\text { IL-10 -1082 A>G, }-592 \\
A>C, T N F-\alpha-308 \text { A }>\text { G, } \\
\text { IFN- } \gamma+874 \text { A }>\text { T }\end{array}$ & $\begin{array}{l}\text { Role of IL-10 - } \\
1082 \mathrm{~A}>\mathrm{G},-592 \\
\mathrm{~A}>\mathrm{C} ; \mathrm{TNF}-\alpha- \\
308 \mathrm{~A}>\mathrm{G} ; \text { and } \\
\text { IFN- } \gamma+874 \\
\mathrm{~A}>\mathrm{T} \text { gene }\end{array}$ & $\begin{array}{l}\text { A statistically significant } \\
\text { correlation was found to be } \\
\text { associated with a high risk of } \\
\text { CMV infection in those with } \\
\text { the IFN- } \gamma \text { A }>\text { T polymorphism }\end{array}$ \\
\hline
\end{tabular}


Table 1. Characteristics of the studies included and association of cytokine gene polymorphisms and viral infections in renal and liver transplant recipients

\begin{tabular}{|c|c|c|c|c|c|c|c|c|}
\hline $\begin{array}{l}\text { Authors and } \\
\text { Year of } \\
\text { Publication } \\
\end{array}$ & $\begin{array}{l}\text { Country of } \\
\text { Origin }\end{array}$ & Study Design & $\begin{array}{l}\text { Sample } \\
\text { Size }\end{array}$ & Ethnicity & $\begin{array}{l}\text { Cytokine } \\
\text { Gene }\end{array}$ & $\begin{array}{l}\text { Allele/Polymorphism/ } \\
\text { SNPs }\end{array}$ & $\begin{array}{l}\text { Intervention/ } \\
\text { Comparison }\end{array}$ & $\begin{array}{l}\text { Impact on Post-transplant } \\
\text { Outcome (Infection) }\end{array}$ \\
\hline & & & & & & & $\begin{array}{l}\text { polymorphisms } \\
\text { was studied in } \\
\text { Hispanic renal } \\
\text { transplant } \\
\text { recipients } \\
\text { (RTRs) with } \\
\text { CMV and } \\
\text { without CMV } \\
\text { infection }\end{array}$ & $\begin{array}{l}\text { (OR: } 3.4, \mathrm{p}: 0.01) \text { in renal } \\
\text { transplant recipients. }\end{array}$ \\
\hline $\begin{array}{l}\text { Allam et al. } \\
2013\end{array}$ & United States & $\begin{array}{l}\text { Retrospective } \\
\text { cohort }\end{array}$ & 1060 & $\begin{array}{l}\text { Mostly } \\
\text { Caucasian }\end{array}$ & IL-28B & $\mathrm{CC}, \mathrm{CT}, \mathrm{TT}$ & CC vs CT vs TT & $\begin{array}{l}\text { Recipient IL-28B status is } \\
\text { important in assessing the final } \\
\text { outcome of graft survival (HR } \\
\text { for TT genotype: } 3.27 \text {, } \\
\mathrm{p}<0.001)\end{array}$ \\
\hline $\begin{array}{l}\text { Lange et al., } \\
2011\end{array}$ & $\begin{array}{l}\text { Germany, } \\
\text { Switzerland }\end{array}$ & Cohort & 91 & $\begin{array}{l}\text { German, } \\
\text { Swiss } \\
\text { nationals }\end{array}$ & Il-28B & $\mathrm{CT} / \mathrm{TT}, \mathrm{CC}$ & $\begin{array}{l}\mathrm{CC} \text { vs } \mathrm{CT} / \mathrm{TT} \\
\text { genotypes }\end{array}$ & $\begin{array}{l}\text { Genotype rs } 12979860 \mathrm{CT} / \mathrm{TT} \\
\text { was identified as a predictor of } \\
\text { liver transplant in HCV } \\
\text { patients (p: } 0.046)\end{array}$ \\
\hline $\begin{array}{l}\text { Mueller JL et } \\
\text { al. } 2016\end{array}$ & United States & Cohort & 264 & $\begin{array}{l}84 \% \\
\text { Caucasians, } \\
6 \% \text { African } \\
\text { Americans, } \\
7 \% \text { Hispanic, } \\
3 \% \text { Asian }\end{array}$ & IL-28B & $\mathrm{CC}, \mathrm{CT}, \mathrm{TT}$ & CC vs CT vs TT & $\begin{array}{l}\text { In patients with } \mathrm{HCV} \text {, the CC } \\
\text { IL-28B variant in both } \\
\text { recipients and donors is } \\
\text { associated with increased rate } \\
\text { of SVR ( } 54 \% \text { vs } 36 \% \text { for non- } \\
\text { CC genotype) in liver } \\
\text { transplantation. }\end{array}$ \\
\hline $\begin{array}{l}\text { Fernandez- } \\
\text { Carrillo C et } \\
\text { al., } 2014\end{array}$ & Spain & Cohort & 86 & Spanish & $\begin{array}{l}\text { IFN- } \lambda 4 \\
\text { IL-28B }\end{array}$ & $\begin{array}{l}\text { rs368234815 genotypes } \\
\text { were defined as TT/TT, } \\
\text { TT/G or G/G. IL-28B } \\
\text { rs12979860 (CC, CT, } \\
\text { TT) and rs8099917 (TT, } \\
\text { GT, GG) }\end{array}$ & $\begin{array}{l}\text { Association } \\
\text { between } \\
\text { recipient IFN- } \lambda 4 \\
\text { favorable } \\
\text { genotype } \\
\text { (TT/TT) and } \\
\text { SVR compared } \\
\text { to unfavorable } \\
\text { genotypes } \\
\text { (TT/G and G/G) }\end{array}$ & $\begin{array}{l}\text { Recipient TT/TT genotype is } \\
\text { associated with a higher SVR } \\
\text { after liver transplantation. }\end{array}$ \\
\hline $\begin{array}{l}\text { Barbera F et } \\
\text { al. } 2015\end{array}$ & Italy & $\begin{array}{l}\text { Retrospective } \\
\text { cohort }\end{array}$ & 57 & Europeans & IL-28B & $\begin{array}{l}\text { Rs12980275 AA, AG- } \\
\text { GG, rs12979860 CC, }\end{array}$ & $\begin{array}{l}\text { Rs } 12980275 \text { AA } \\
\text { vs AG vs GG, }\end{array}$ & $\begin{array}{l}\text { Homozygous allele of } \\
\text { rs12979860 was associated }\end{array}$ \\
\hline
\end{tabular}


Table 1. Characteristics of the studies included and association of cytokine gene polymorphisms and viral infections in renal and liver transplant recipients

\begin{tabular}{|c|c|c|c|c|c|c|c|c|}
\hline $\begin{array}{l}\text { Authors and } \\
\text { Year of } \\
\text { Publication }\end{array}$ & $\begin{array}{l}\text { Country of } \\
\text { Origin }\end{array}$ & Study Design & $\begin{array}{l}\text { Sample } \\
\text { Size }\end{array}$ & Ethnicity & $\begin{array}{l}\text { Cytokine } \\
\text { Gene }\end{array}$ & $\begin{array}{l}\text { Allele/Polymorphism/ } \\
\text { SNPs }\end{array}$ & $\begin{array}{l}\text { Intervention/ } \\
\text { Comparison }\end{array}$ & $\begin{array}{l}\text { Impact on Post-transplant } \\
\text { Outcome (Infection) }\end{array}$ \\
\hline & & & & & & $\begin{array}{l}\text { CT-TT, rs8099917 TT, } \\
\text { TG-GG }\end{array}$ & $\begin{array}{l}\text { rs } 12979860 \mathrm{CC} \\
\text { vs CT vs TT, } \\
\text { rs8099917 TT } \\
\text { vs TG vs GG }\end{array}$ & $\begin{array}{l}\text { with SVR independent of the } \\
\text { donor's genotype in patients } \\
\text { with HCV in liver transplant } \\
\text { patients. }\end{array}$ \\
\hline $\begin{array}{l}\text { Firpi RJ et al., } \\
2013\end{array}$ & United States & $\begin{array}{l}\text { Retrospective } \\
\text { cohort }\end{array}$ & 135 & Caucasian & IL-28B & $\mathrm{CC}, \mathrm{CT}, \mathrm{TT}$ & CC vs CT vs TT & $\begin{array}{l}\text { The CC genotype had less } \\
\text { fibrosis, but it was not } \\
\text { statistically significant. No } \\
\text { statistically significant } \\
\text { difference in patient survival } \\
\text { was determined in HCV } \\
\text { patients (CC aHR: } 1.12 \text { (p: } \\
0.73 \text { ), non-CC: } 1.30 \text { (p: } 0.41)\end{array}$ \\
\hline $\begin{array}{l}\text { Monaghan } \\
\text { KG et al., } \\
2015\end{array}$ & United States & $\begin{array}{l}\text { Retrospective } \\
\text { cohort }\end{array}$ & 22 & $\begin{array}{l}\text { White } \\
\text { Caucasian, } \\
\text { African } \\
\text { American } \\
\text { and } \\
\text { Hispanics }\end{array}$ & IFN- $\lambda 3$ & $\begin{array}{l}\mathrm{rs} 12979860(\mathrm{C} / \mathrm{T}) \text { and } \\
\mathrm{rs} 8099917(\mathrm{~T} / \mathrm{G})\end{array}$ & $\begin{array}{l}\text { recipient and } \\
\text { donor genotype } \\
\text { associations } \\
\text { between each } \\
\text { SNP } \\
\text { (rs12979860 C } \\
\text { and rs8099917 } \\
\text { T) and SVR } \\
\text { status }\end{array}$ & $\begin{array}{l}\text { Transplantation of a } \\
\text { rs12979860 CC graft has a } \\
\text { more favorable post-transplant } \\
\text { antiviral response among those } \\
\text { who are HCV-positive and in } \\
\text { those post-transplantation is } \\
\text { more likely to achieve SVR. }\end{array}$ \\
\hline $\begin{array}{l}\text { Cisneros E et } \\
\text { al., } 2012\end{array}$ & Spain & $\begin{array}{l}\text { Retrospective } \\
\text { Cohort }\end{array}$ & 90 & Spanish & IL-28B & $\mathrm{CC}, \mathrm{CT}, \mathrm{TT}$ & CC vs CT vs TT & $\begin{array}{l}\text { More patients with the allele rs } \\
12979860-\mathrm{T} \text { had severe HCV } \\
\text { recurrence than those without } \\
\text { it }(82.9 \% \text { vs } 53.1 \% \text {, OR: } 4.30 \text {, } \\
\text { p: } 0.0028) \text { in liver transplant } \\
\text { patients. }\end{array}$ \\
\hline $\begin{array}{l}\text { El Awady } \\
\text { MK et al., } \\
2014\end{array}$ & Egypt & Cohort & 50 & Egyptians & $\begin{array}{l}\text { IL-28B, IL- } \\
1 \mathrm{~B}\end{array}$ & $\begin{array}{l}\text { CC, CT, TT of IL-1B, } \\
\text { CC, CT, TT of IL-28B }\end{array}$ & $\mathrm{CC}$ vs $\mathrm{CT}$ vs TT & $\begin{array}{l}\text { In patients with chronic } \mathrm{HCV} \\
\text { infection, the CC genotype of } \\
\text { the IL-28B gene had a } \\
\text { correlation with higher rates of } \\
\text { disease-free survival at } 62.5 \% \\
\text { (p: } 0.025 \text { ) in liver transplant } \\
\text { recipients. }\end{array}$ \\
\hline $\begin{array}{l}\text { Kawaoka T et } \\
\text { al., } 2012\end{array}$ & Japan & Cohort & 20 & Japanese & IL-28B & $\mathrm{TG}+\mathrm{GG}, \mathrm{TT}$ & TG+GG vs TT & $\begin{array}{l}\text { In patients with HCV who } \\
\text { completed IFN therapy, the } \\
\text { SVR rate of donors TT group }\end{array}$ \\
\hline
\end{tabular}


Table 1. Characteristics of the studies included and association of cytokine gene polymorphisms and viral infections in renal and liver transplant recipients

\begin{tabular}{|c|c|c|c|c|c|c|c|c|}
\hline $\begin{array}{l}\text { Authors and } \\
\text { Year of } \\
\text { Publication }\end{array}$ & $\begin{array}{l}\text { Country of } \\
\text { Origin }\end{array}$ & Study Design & $\begin{array}{l}\text { Sample } \\
\text { Size }\end{array}$ & Ethnicity & $\begin{array}{l}\text { Cytokine } \\
\text { Gene }\end{array}$ & $\begin{array}{l}\text { Allele/Polymorphism/ } \\
\text { SNPs }\end{array}$ & $\begin{array}{l}\text { Intervention/ } \\
\text { Comparison }\end{array}$ & $\begin{array}{l}\text { Impact on Post-transplant } \\
\text { Outcome (Infection) }\end{array}$ \\
\hline
\end{tabular}

Publication

Harada N et Japan $\quad$ Cohort
$\begin{aligned} & \text { al., } 2014\end{aligned}$

was higher than the $\mathrm{TG}+\mathrm{GG}$ group (73\% vs 20\%) while the recipient's alleles were similar among liver transplant recipients.

Presence of the TT allele in the recipient or donor corresponded to SVR of $53 \%$ and $48 \%$, respectively in patients with HCV. Difference of SVR between TT and TG/GG in recipient was statistically significant in liver transplant recipients.

\begin{tabular}{|c|c|c|c|c|c|c|c|c|}
\hline $\begin{array}{l}\text { Coto-Llerena } \\
\text { M et al. } 2011\end{array}$ & Spain & Cohort & 128 & Spanish & IL-28B & $\begin{array}{l}\text { Rs } 12989860, \mathrm{CC}, \mathrm{CT} \text {, } \\
\mathrm{TT}, \mathrm{rs} 8099917 \mathrm{TT}, \mathrm{GT} \text {, } \\
\text { GG }\end{array}$ & $\begin{array}{l}\text { CC vs CT vs TT } \\
\text { in rs } 1298960, \\
\text { TT, GT, GG in } \\
\text { rs } 8099917\end{array}$ & $\begin{array}{l}\text { Antiviral therapy response rate } \\
\text { was higher for recipient } \\
\text { genotype CC compared to } \\
\text { CT/TT before and after liver } \\
\text { transplantation in HCV- } \\
\text { infected patients }(100 \% \text { vs } \\
48 \% \text {, p:0.013) }\end{array}$ \\
\hline $\begin{array}{l}\text { Charlton MR } \\
\text { et al., } 2011\end{array}$ & United States & $\begin{array}{l}\text { Retrospective } \\
\text { cohort }\end{array}$ & 189 & $\mathrm{~N} / \mathrm{R}$ & IL-28B & $\mathrm{CC}, \mathrm{CT}, \mathrm{TT}$ & CC vs CT vs TT & $\begin{array}{l}\text { The TT genotype was } \\
\text { associated with more rapid } \\
\text { fibrosis (p: } 0.024) \text {. Donor and } \\
\text { recipient CC variant were } \\
\text { associated with increased rate } \\
\text { of sustained virologic response } \\
\text { ( } 59 \% \text { and } 58 \% \text {, respectively) } \\
\text { in liver transplant patients. }\end{array}$ \\
\hline $\begin{array}{l}\text { Duarte-Rojo } \\
\text { A et al., } 2012\end{array}$ & United States & Cohort & 255 & $\mathrm{~N} / \mathrm{R}$ & IL-28B & $\mathrm{CC}, \mathrm{CT}, \mathrm{TT}$ & $\begin{array}{l}\mathrm{CC} \text { vs non-CC } \\
\text { genotype }\end{array}$ & $\begin{array}{l}\text { In liver transplant recipients } \\
\text { with } \mathrm{HCV} \text {, the CC genotype } \\
\text { from the donor showed a } \\
\text { higher rate of cirrhosis } \\
\text { progression (HR: } 5.96 \text { ), liver- } \\
\text { related death or re- } \\
\text { transplantation. Donor CC } \\
\text { genotype favored }\end{array}$ \\
\hline
\end{tabular}


Table 1. Characteristics of the studies included and association of cytokine gene polymorphisms and viral infections in renal and liver transplant recipients

\begin{tabular}{|c|c|c|c|c|c|c|c|c|}
\hline $\begin{array}{l}\text { Authors and } \\
\text { Year of } \\
\text { Publication }\end{array}$ & $\begin{array}{l}\text { Country of } \\
\text { Origin }\end{array}$ & Study Design & $\begin{array}{l}\text { Sample } \\
\text { Size }\end{array}$ & Ethnicity & $\begin{array}{l}\text { Cytokine } \\
\text { Gene }\end{array}$ & $\begin{array}{l}\text { Allele/Polymorphism/ } \\
\text { SNPs }\end{array}$ & $\begin{array}{l}\text { Intervention/ } \\
\text { Comparison }\end{array}$ & $\begin{array}{l}\text { Impact on Post-transplant } \\
\text { Outcome (Infection) }\end{array}$ \\
\hline
\end{tabular}

Publication

Świątek-

Kościelna B

Poland

Cohort

et al., 2017

Ge D et al., United States Cohort

2009

Li W et al., China

Cohort

200

2012

Li W et al., China
2011
Li Y et al. $\quad$ China

Cohort

648

Chinese Han population

2017

\section{6}

Polish

nationals of

Caucasian

ethnicity population

Retrospective

231

Chinese
IL-10

$819(\mathrm{C} / \mathrm{T}) \mathrm{rs} 1800871$, $592(\mathrm{C} / \mathrm{A}) \mathrm{rs} 1800872$ and $+4529(\mathrm{~A} / \mathrm{G}) \mathrm{rs} 3024498$.

alleles

inflammation and fibrosis. Only after antiviral therapy does the donor $\mathrm{CC}$ genotype become favorable

IL-10 SNPs are associated with disease severity. -592C allele is associated with mild hepatic inflammation and is protective against tissue inflammation vs A allele (OR: 0.592 , p: 0.035). -819C allele might be associated with SVR (OR: 0.570, p: 0.028) in liver transplant patients.

In patients with European ancestry, and Hispanic and African American patients, the $\mathrm{CC}$ genotype is associated with a greater rate of SVR than the TT genotype (OR: $7.3,6.1,5.6$, respectively) in liver transplant recipients.

Chinese Han IL-18, IL- alleles of IL-18, IL-28B GG, GT, TT $28 \mathrm{~B}$

IL-28B

rs12979860, rs12980275 and rs8099917

IL-28B

TT genotype, CC genotype, GG genotype

CC vs TT, CC

vs CT

rs12979860, rs12980275 vs rs8099917

TT vs CC vs GG
Patients with genetic variants of IL-28B had more hepatic dysfunction from HBV infection. $G$ allele recipients was associated with higher ALT \& AST levels $(\mathrm{p}<0.05)$ in liver transplant.

IL 28-B G allele is a predictor of hepatic injury after liver transplantation.

Recipients with CC genotype of rs12979860 and AA genotype of rs8099917 in IL28B had lower peripheral platelet count after liver 
Table 1. Characteristics of the studies included and association of cytokine gene polymorphisms and viral infections in renal and liver transplant recipients

\begin{tabular}{|c|c|c|c|c|c|c|c|c|}
\hline $\begin{array}{l}\text { Authors and } \\
\text { Year of } \\
\text { Publication }\end{array}$ & $\begin{array}{l}\text { Country of } \\
\text { Origin }\end{array}$ & Study Design & $\begin{array}{l}\text { Sample } \\
\text { Size }\end{array}$ & Ethnicity & $\begin{array}{l}\text { Cytokine } \\
\text { Gene }\end{array}$ & $\begin{array}{l}\text { Allele/Polymorphism/ } \\
\text { SNPs }\end{array}$ & $\begin{array}{l}\text { Intervention/ } \\
\text { Comparison }\end{array}$ & $\begin{array}{l}\text { Impact on Post-transplant } \\
\text { Outcome (Infection) }\end{array}$ \\
\hline
\end{tabular}

Publication

Abbott et al., New Zealand Cohort 2007

Ben-Ari $\mathrm{Z}$ et Israel

al. 2003

Cohort

77

Israeli

nationals
TNF- $\alpha$, IL- A/A genotype of

6, IL-10, IFN- $\gamma$

IFN- $\gamma$

Control group vs

patients with

chronic HBV

infection

transplantation in the first 4

days. They concluded no differences in ALT and AST

between recipients with different genotypes after transplantation.

$12 / 12$

The IFN- $\gamma$ CA genotype was associated with the risk of

chronic HBV infection because of a dominant effect of the 12 CA-repeat allele on 12/non-12, homozygous non-12/non-12 developing natural immunity in homozygotes (OR: 5.8, p: 0.003 ) and heterozygotes (OR: $2.7, \mathrm{p:}$ 0.01) in liver transplant patients.

Authors did not observe any significant dissimilarity in the HBV infection outcomes due to TNF- $\alpha$, IL-6 and IL-10 polymorphisms. $65.2 \%$ of patients exhibited potential to produce IFN- $\gamma$ in low levels (A/A genotype) compared to $37.5 \%$ in the control group ( $\mathrm{p}$ : 0.003 ) in liver transplant patients

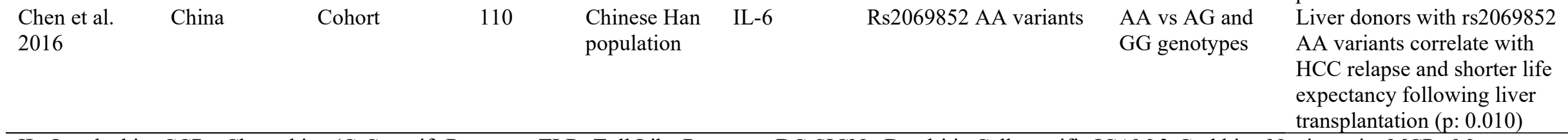

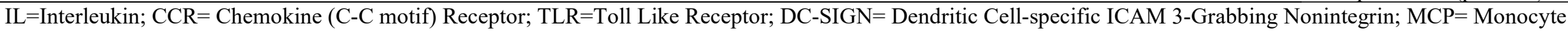

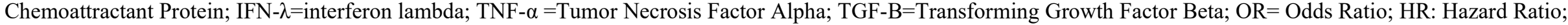
aHR: Adjusted Hazard Ratio; CMV = Cytomegalovirus; HBV = Hepatitis B Virus; HCV = Hepatitis C Virus; SVR = Sustained Virologic Response; $\mathrm{p}=\mathrm{p}$-value; $\mathrm{HCC}=$ Hepatocellular Carcinoma; IFN- $\gamma=$ Interferon Gamma; ALT=Alanine Transaminase; AST= Aspartate Transaminase; SNP=Single Nucleotide Protein; N/R=Not Reported 


\section{S3: 2009 PRISMA Checklist}

\begin{tabular}{|c|c|c|c|}
\hline Section/topic & \# & Checklist item & $\begin{array}{l}\text { Reported on } \\
\text { page \# }\end{array}$ \\
\hline \multicolumn{4}{|l|}{ TITLE } \\
\hline Title & 1 & Identify the report as a systematic review, meta-analysis, or both. & 2 \\
\hline Structured summary & 2 & $\begin{array}{l}\text { Provide a structured summary including, as applicable: background; objectives; data sources; study } \\
\text { eligibility criteria, participants, and interventions; study appraisal and synthesis methods; results; } \\
\text { limitations; conclusions and implications of key findings; systematic review registration number. }\end{array}$ & 1 \\
\hline \multicolumn{4}{|l|}{ INTRODUCTION } \\
\hline Rationale & 3 & Describe the rationale for the review in the context of what is already known. & $2-3$ \\
\hline Objectives & 4 & $\begin{array}{l}\text { Provide an explicit statement of questions being addressed with reference to } \\
\text { participants, interventions, comparisons, outcomes, and study design (PICOS). }\end{array}$ & 3 \\
\hline \multicolumn{4}{|l|}{ METHODS } \\
\hline $\begin{array}{l}\text { Protocol and } \\
\text { registration }\end{array}$ & 5 & $\begin{array}{l}\text { Indicate if a review protocol exists, if and where it can be accessed (e.g., Web address), and, if } \\
\text { available, provide registration information including registration number. }\end{array}$ & NA \\
\hline Eligibility criteria & 6 & $\begin{array}{l}\text { Specify study characteristics (e.g., PICOS, length of follow-up) and report characteristics (e.g., } \\
\text { years considered, language, publication status) used as criteria for eligibility, giving rationale. }\end{array}$ & $3-4$ \\
\hline Search & 8 & $\begin{array}{l}\text { Present full electronic search strategy for at least one database, including any limits } \\
\text { used, such that it could be repeated. }\end{array}$ & Appendix S1 \\
\hline Study selection & 9 & $\begin{array}{l}\text { State the process for selecting studies (i.e., screening, eligibility, included in systematic review, and, } \\
\text { if applicable, included in the meta-analysis). }\end{array}$ & 3,4 \\
\hline Data collection process & 10 & $\begin{array}{l}\text { Describe method of data extraction from reports (e.g., piloted forms, independently, in duplicate) } \\
\text { and any processes for obtaining and confirming data from investigators. }\end{array}$ & $\begin{array}{l}3-4, \text { Appendix } \\
\text { S2 }\end{array}$ \\
\hline Data items & 11 & $\begin{array}{l}\text { List and define all variables for which data were sought (e.g., PICOS, funding sources) } \\
\text { and any assumptions and simplifications made. }\end{array}$ & $\begin{array}{l}3-4, \text { Appendix } \\
\text { S2 }\end{array}$ \\
\hline $\begin{array}{l}\text { Risk of bias in } \\
\text { individual studies }\end{array}$ & 12 & $\begin{array}{l}\text { Describe methods used for assessing risk of bias of individual studies (including specification of } \\
\text { whether this was done at the study or outcome level), and how this information is to be used in any } \\
\text { data synthesis. }\end{array}$ & 3-4, Fig. 2 \\
\hline Summary measures & 13 & State the principal summary measures (e.g., risk ratio, difference in means). & NA \\
\hline Synthesis of results & 14 & $\begin{array}{l}\text { Describe the methods of handling data and combining results of studies, if done, } \\
\text { including measures of consistency }\left(\text { e.g., } \mathrm{I}^{2}\right) \text { for each meta-analysis. }\end{array}$ & NA \\
\hline $\begin{array}{l}\text { Risk of bias across } \\
\text { studies }\end{array}$ & 15 & $\begin{array}{l}\text { Specify any assessment of risk of bias that may affect the cumulative evidence (e.g., publication } \\
\text { bias, selective reporting within studies). }\end{array}$ & 4, Fig. 2 \\
\hline
\end{tabular}




\begin{tabular}{|c|c|c|c|}
\hline Section/topic & \# & Checklist item & $\begin{array}{l}\text { Reported on } \\
\text { page \# }\end{array}$ \\
\hline \multicolumn{4}{|l|}{ RESULTS } \\
\hline Study selection & 17 & $\begin{array}{l}\text { Give numbers of studies screened, assessed for eligibility, and included in the review, } \\
\text { with reasons for exclusions at each stage, ideally with a flow diagram. }\end{array}$ & 3-4, Fig. 1 \\
\hline Study characteristics & 18 & $\begin{array}{l}\text { For each study, present characteristics for which data were extracted (e.g., study size, PICOS, } \\
\text { follow-up period) and provide the citations. }\end{array}$ & $5-12$, Table 1 \\
\hline $\begin{array}{l}\text { Risk of bias within } \\
\text { studies }\end{array}$ & 19 & $\begin{array}{l}\text { Present data on risk of bias of each study and, if available, any outcome level assessment (see item } \\
\text { 12). }\end{array}$ & $\begin{array}{l}\text { 13-15, Table 2, } \\
\text { Fig. } 2\end{array}$ \\
\hline $\begin{array}{l}\text { Results of individual } \\
\text { studies }\end{array}$ & 20 & $\begin{array}{l}\text { For all outcomes considered (benefits or harms), present, for each study: (a) simple summary data } \\
\text { for each intervention group (b) effect estimates and confidence intervals, ideally with a forest plot. }\end{array}$ & NA \\
\hline Synthesis of results & 21 & $\begin{array}{l}\text { Present results of each meta-analysis done, including confidence intervals and measures } \\
\text { of consistency. }\end{array}$ & NA \\
\hline $\begin{array}{l}\text { Risk of bias across } \\
\text { studies }\end{array}$ & 22 & Present results of any assessment of risk of bias across studies (see Item 15). & $\begin{array}{l}\text { 13-15, Table 2, } \\
\text { Fig. } 2\end{array}$ \\
\hline Additional analysis & 23 & $\begin{array}{l}\text { Give results of additional analyses, if done (e.g., sensitivity or subgroup analyses, meta-regression } \\
\text { [see Item 16]). }\end{array}$ & NA \\
\hline Summary of evidence & 24 & $\begin{array}{l}\text { Summarize the main findings including the strength of evidence for each main outcome; consider } \\
\text { their relevance to key groups (e.g., healthcare providers, users, and policy makers). }\end{array}$ & $18-20$ \\
\hline Limitations & 25 & $\begin{array}{l}\text { Discuss limitations at study and outcome level (e.g., risk of bias), and at review-level } \\
\text { (e.g., incomplete retrieval of identified research, reporting bias). }\end{array}$ & 20 \\
\hline Conclusions & 26 & $\begin{array}{l}\text { Provide a general interpretation of the results in the context of other evidence, and implications for } \\
\text { future research. }\end{array}$ & 20 \\
\hline \multicolumn{4}{|l|}{ FUNDING } \\
\hline Funding & 27 & $\begin{array}{l}\text { Describe sources of funding for the systematic review and other support (e.g., supply of data); role } \\
\text { of funders for the systematic review. }\end{array}$ & 20 \\
\hline
\end{tabular}

